LAWRENCE F. KATZ

Harvard University and National Bureau of Economic Research

LAWRENCE H. SUMMERS

Harvard University and National Bureau of Economic Research

\title{
Industry Rents: Evidence and Implications
}

THE PAST FEW years have witnessed a renewed interest in the sectoral composition as well as the overall level of the economy's output. Evidence suggesting that the bulk of employment growth in the United States has occurred in sectors that are thought to provide "low wage, bad jobs" rather than in sectors that provide "high wage, good jobs" is often cited as an argument that U.S. economic performance has been poor in recent years. ${ }^{1}$ At the same time, advocates of industrial policies assert that some industries are "better" for a national economy than others and urge that the government manage its influence on the economy to promote growth and competitiveness.

This paper draws heavily upon and extends our study "Can Inter-Industry Wage Differentials Justify Strategic Trade Policy?' in R. Feenstra, ed., Trade Policies for International Competitiveness (University of Chicago Press, forthcoming). We are grateful to Zvi Griliches and Bronwyn Hall for providing us with updated versions of the R\&D Master File data set, to Richard Baldwin for providing us with data on Airbus, to Robert Stern for providing us with trade flow data, to Glen Hubbard for providing us with data on market structure variables, and to David Cutler and Cecilia Rouse for expert research assistance. We thank William Dickens and Alan Krueger for many helpful discussions. Financial support from the following sources is also gratefully acknowledged: National Science Foundation grants SES 88-09200 and SES 85-53244 and an NBER Olin Fellowship in Economics. The principal data sets used in this research, the R\&D Master File and the NBER Trade and Immigration Datasets, are maintained by the National Bureau of Economic Research.

1. Robert M. Costrell, "The Effects of Industry Employment Shifts on Wage Growth: 1948-87' ' (a study prepared for the Joint Economic Committee, August 1988), documents the claim that the bulk of employment growth in the United States over the 1981-87 period occurred in low-wage sectors. 
Focusing on the sectoral composition of economic activity makes little sense from the perspective of economists' standard theory of competitive markets. In competitive markets factor prices are equalized across sectors and firms hire factors of production up to the point where their marginal productivity equals their cost. Since labor is freely mobile, there are no good and bad jobs. It follows almost immediately that there is no advantage to policies that alter the composition of output. Thus any economic justification for worrying about the sectoral composition of output must rely on the presence of market imperfections that drive a wedge between the marginal productivities of factors in different uses. Such imperfections are likely to cause factors in certain sectors to earn economic rents.

This paper presents estimates of the rents accruing to labor and capital in different American industries. Whereas the recent literature on strategic trade policy has examined policy measures that can shift monopoly rents between nations, our estimates suggest that capital owners in the American economy receive few monopoly rents. ${ }^{2}$ By contrast, even in sectors where unions do not play an important role, there appear to be significant interindustry wage differentials that cannot be wholly attributed to differences in skill or working conditions. This suggests that in an economically meaningful sense there are good and bad jobs and that policies which shift the composition of output may have important effects on economic efficiency. Issues associated with labor market rents almost certainly dwarf those associated with monopoly rents earned by capitalists. For the American nonfinancial corporate sector in 1987, employee compensation made up 82 percent of value added, whereas operating profits made up only 18 percent, ${ }^{3}$ with much of that attributable to the normal return to capital rather than monopoly profits.

We begin by examining the extent to which shareholders in certain industries receive monopoly rents. Examining data both on rates of profit in different manufacturing industries and on the $q$ ratio of the

2. The strategic trade policy literature is surveyed by Avinash Dixit, "Strategic Aspects of Trade Policy," in Truman F. Bewley, ed., Advances in Economic TheoryFifth World Congress (Cambridge University Press, 1987), pp. 329-62, and is debated in Paul R. Krugman, ed., Strategic Trade Policy and the New International Economics (MIT Press, 1987). Jagdish Bhagwati, Protectionism (MIT Press, 1988), provides a critical review of the strategic trade policy literature.

3. Economic Report of the President, February 1988, p. 262. 
market valuation of companies to the replacement cost of their assets, we find evidence of only relatively minor monopoly profits. Because profits account for a relatively small share of value added, our results suggest that even quite small differences in wages across industries have more significant allocative consequences than observed variations in capital rents.

We therefore survey and add to the burgeoning literature on noncompetitive wage differentials. Until fairly recently, labor economists assumed such differentials existed. According to John Dunlop, "The notion that wage differentials for carefully defined job classifications persist among establishments in the same labor market, and that they are not to be explained away as compensating differentials for working conditions or the quality of the work force, are propositions that would have been almost universally accepted as fact by students of the labor market and wage determination of the period 1930-60." Such differentials are the critical element in the dual labor market theories of Doeringer and Piore. ${ }^{4}$

After first presenting estimates of skill-adjusted interindustry wage differentials, and showing that they are remarkably constant across time and space, we consider in detail neoclassical arguments that, rather than representing labor market rents, these differentials can be explained by unmeasured labor quality and differences in working conditions. We discount these possibilities as complete explanations for observed differentials, on the basis of several types of evidence, including longitudinal evidence on workers who switch industries and direct evidence on rents coming from the extent of labor market queues.

Having suggested the existence of labor market rents, we go on to consider their sources. In part, we suspect they arise because the considerations of motivation, morale, stability, and recruiting, stressed by writers on efficiency wages, substantially reduce the costs to firms of raising their wages. ${ }^{5} \mathrm{~A}$ significant fraction of the cost of paying supracompetitive wages is recouped in the form of higher productivity. Under

4. John T. Dunlop, “Labor Markets and Wage Determination: Then and Now," in Bruce E. Kaufman, ed., How Labor Markets Work (Lexington, Mass.: Lexington, 1988), p. 57; and Peter B. Doeringer and Michael J. Piore, Internal Labor Markets and Manpower Analysis (D. C. Heath, 1971).

5. Many of the important papers in this literature are collected in George A. Akerlof and Janet L. Yellen, eds., Efficiency Wage Models of the Labor Market (Cambridge University Press, 1986). 
these circumstances workers, even when they are not formally organized, are able to capture a large part of the rents that firms earn. We document that wages are sensitive to the losses labor can inflict on firms even in nonunion settings. In industries like steel and automobiles, where it is tempting to attribute high wages to union power, we demonstrate that there are substantial wage premiums that predate union organization.

In the next section we consider the implications of noncompetitive wage differentials for trade and industrial policies. Their potential significance for policy has played a prominent role in trade theory at least since the work of Hagen and of Bhagwati and Ramaswami. ${ }^{6}$ We find that industry wage differences provide a rationale similar to those advanced by some advocates of industrial policy. Policies that encourage employment in high-wage sectors are likely to transfer labor from lowto high-productivity uses and thereby increase total output. Both stylized calculations and consideration of actual examples suggest these effects may be quantitatively important.

Given the concern about trade and its impact on U.S. industries, we then consider the extent of both labor and capital market rents in the products the United States imports and exports. We reach three main conclusions. First, at least within the manufacturing sector, export industries carry more rents than those that compete with imports. This finding reinforces the traditional conclusion that trade is beneficial. Second, it does not appear, at least through 1984, that changing trade patterns have disproportionately hurt the high-wage portion of the U.S. manufacturing sector. Instead, as one would expect given America's continuing technological preeminence, import competition has primarily affected low-wage parts of the U.S. manufacturing sector. Steel and automobiles-high-wage industries that export weakly and have been battered by import competition-are exceptions to these generalizations. Third, the pattern of exporting high-wage premium goods while importing low-wage goods is apparently a pattern common to developed countries.

We conclude the paper by offering a tentative assessment of the implications of our results for actual policy. Our analysis suggests that

6. Everett E. Hagen, “An Economic Justification of Protectionism,"' Quarterly Journal of Economics, vol. 72 (November 1958), pp. 496-514; and Jagdish Bhagwati and V. K. Ramaswami, "Domestic Distortions, Tariffs and the Theory of Optimum Subsidy," Journal of Political Economy, vol. 71 (February 1963). 
policies directed at reducing imports are likely to have extremely adverse effects on economic welfare, whereas certain measures directed at promoting exports may increase welfare because of the high wages associated with American export industries. Any economic case for activist policy must of course be tempered by a recognition of the formidable difficulties of successfully implementing structural policies. It does appear, however, that in making decisions with nonneutral effects across sectors, the government would do well to take account of the evidence on industry wage premiums.

\section{Capital Rents}

The literature on strategic trade policy has concentrated on the potential for trade policies to shift monopoly rents between firms. It has focused on strategies that nations can pursue to enable domestic firms either to gain monopoly power by, for example, running down learning curves ahead of foreign competitors or to reap a large share of oligopoly profits by being well positioned to retaliate against rivals that cut prices. Insofar as strategic trade policies succeed, one would expect them to lead firms to earn profits in excess of their costs of capital. A first way of assessing the potential significance of product market distortions for trade policy is therefore to examine the extent to which capital in certain industries receives abnormal returns.

To shed light on this issue, we present in table 1 two indicators of the return to capital in twenty two-digit manufacturing industries. ${ }^{7}$ The first column shows the average after-tax rate of return, calculated as the ratio of after-tax operating profits computed on an inflation-adjusted basis to the replacement cost of the capital stock, for these twenty industries averaged over the 1960-85 period. The second column presents estimates of the $q$ ratio of the market value of firms to the replacement cost of their assets. ${ }^{8}$ The third and fourth columns provide the analogous figures for the 1981-85 subperiod.

7. We focus on capital rents in the manufacturing sector, since satisfactory data on capital inputs and firm market value were not available for other sectors.

8. The industry-level profit rates and $q$ ratios were aggregated up from data on individual firms contained in the R\&D Master File panel data set developed and maintained by the NBER productivity program. We computed the after-tax net rate of return and $q$ ratio for 
Table 1. Capital Rents in Twenty U.S. Manufacturing Industries, 1960-85 ${ }^{\text {a }}$

\begin{tabular}{|c|c|c|c|c|}
\hline \multirow[b]{2}{*}{ Industry } & \multicolumn{2}{|c|}{$1960-85$} & \multicolumn{2}{|c|}{$1981-85$} \\
\hline & $\begin{array}{l}\text { After-tax } \\
\text { profit rate }\end{array}$ & $q$ & $\begin{array}{l}\text { After-tax } \\
\text { profit rate }\end{array}$ & $q$ \\
\hline Lumber & 0.050 & 1.16 & 0.009 & 0.64 \\
\hline Furniture & 0.043 & 0.91 & 0.043 & 0.99 \\
\hline Stone, glass, clay & 0.043 & 0.91 & 0.011 & 0.52 \\
\hline Primary metals & 0.028 & 0.69 & -0.022 & 0.43 \\
\hline Fabricated metals & 0.057 & 0.97 & 0.037 & 0.77 \\
\hline Machinery, except electrical & 0.061 & 1.43 & 0.021 & 0.93 \\
\hline Electrical machinery & 0.070 & 1.68 & 0.045 & 1.31 \\
\hline Transportation equipment & 0.066 & 1.09 & 0.054 & 0.73 \\
\hline Scientific instruments & 0.091 & 3.24 & 0.042 & 1.22 \\
\hline Miscellaneous manufacturing & 0.071 & 1.33 & 0.056 & 1.14 \\
\hline Food & 0.060 & 1.21 & 0.061 & 0.91 \\
\hline Tobacco & 0.081 & 1.19 & 0.095 & 0.93 \\
\hline Textiles & 0.042 & 0.82 & 0.018 & 0.59 \\
\hline Apparel & 0.070 & 1.16 & 0.074 & 1.01 \\
\hline Paper & 0.066 & 1.43 & 0.038 & 1.02 \\
\hline Printing & 0.086 & 1.90 & 0.073 & 1.45 \\
\hline Chemicals & 0.069 & 1.64 & 0.038 & 0.91 \\
\hline Petroleum & 0.053 & 0.87 & 0.028 & 0.53 \\
\hline Rubber & 0.054 & 1.24 & 0.021 & 0.78 \\
\hline Leather & 0.064 & 1.09 & 0.043 & 0.84 \\
\hline Weighted average & 0.060 & 1.28 & 0.035 & 0.85 \\
\hline
\end{tabular}

Source: Authors' calculations using the NBER R\&D Master File. The calculations and variable definitions are described in detail in the appendix. Industries defined by two-digit census industry codes (CIC).

a. The capital rent measures are defined as follows: $q$ is the sum of the value of equity and debt less the value of short-term assets, divided by the inflation-adjusted capital stock (NETCAP); NETCAP is given by the net value of plant and equipment plus the value of inventories plus investments in unconsolidated subsidiaries, others and intangibles, all adjusted for inflation; the after-tax profit rate is given by inflation adjusted after-tax net income divided by NETCAP.

b. NETCAP is the weight.

The figures in the table show that owners of capital in the American economy do not receive large monopoly rents. The average profit rate of 6.0 percent for $1960-85$ is close to plausible estimates of the cost of capital. More striking, the average value of $q$ is actually less than one in the 1981-85 period and not much greater than one for the $1960-85$ period as a whole, implying that fixed assets are sufficient or close to sufficient to entirely account for the value of the average firm. Of the twenty two-

each industry in each year from 1960 to 1985 . The reported figures are the arithmetic averages of the annual profit rates and $q$ ratios for each industry for the relevant period. Further information on the construction of these profit rate and $q$ ratio measures is provided in the appendix. 
digit industries considered here, only one (scientific instruments) for the 1960-85 period has what appears to be a very high $q$. But since firms in this industry invest far more heavily in $R \& D$ than average firms, its high $q$ probably cannot be primarily attributed to monopoly power. ${ }^{9}$

Our conclusion that corporate share prices do not capitalize large monopoly rents seems to have considerable validity internationally as well as domestically. Hoshi, Kashyap, and Scharfstein report that the average value of $q$ for a large sample of Japanese firms is close to one. ${ }^{10}$

An extensive literature in industrial organization has sought to correlate profit measures like these with industry characteristics. ${ }^{11}$ Although some evidence has emerged that profit rates are correlated with variables like concentration ratios, which might be thought to reflect monopoly power, the size of the effects is not impressive. Given that capital accounts for only about 12.7 percent of value added in our sample of manufacturing industries, even if we treat all after-tax profit rates above the average rate as arising wholly out of monopoly power, monopoly rents earned by capitalists account for less than 1.7 percent of value added in manufacturing. ${ }^{12}$ Of course, given the host of measurement problems in determining our profit rates and the fact that many firms have unmeasured intangible assets, this calculation surely overstates the real magnitude of monopoly rents earned by shareholders. Furthermore, as we document later, the interindustry variation in rents earned by capital (even considering the potential errors in our measures) seems to be small compared with the variation in labor rents.

9. For example, data derived from the National Science Foundation, $R \& D$ in Industry (1981), indicate that in $1981 \mathrm{R} \& \mathrm{D}$ expenditures as a fraction of sales were 7.4 percent in instruments as opposed to 2.85 percent in manufacturing as a whole.

10. Takeo Hoshi, Anil Kashyap, and David Scharfstein, "Corporate Structure, Liquidity, and Investment: Evidence from Japanese Panel Data," paper presented at the National Bureau of Economic Research Program on Economic Fluctuations Research Meeting, October 14, 1988.

11. Fora recent survey, see Richard Schmalensee, "Inter-Industry Studies of Structure and Performance," in Richard Schmalensee and Robert Willig, eds., Handbook of Industrial Organization (Amsterdam: North-Holland, forthcoming).

12. Authors' calculations using U.S. Bureau of the Census, 1985 Annual Survey of Manufactures: Statistics for Industry Groups and Industries, M85 (AS)-1 (Department of Commerce, 1987), and data from the NBER R\&D Master File. We define value added in our manufacturing sample as the sum of total employee compensation, after-tax profits plus net interest, and corporate profits taxes. The calculation in the text uses the 1984 level of total employee compensation and computes the level of profits by multiplying the 1984 inflation-adjusted capital stock by the average rate of profit for the 1960 to 1985 period. 
These results should not be taken to imply that the assumption of perfect competition in product markets is a good one. Instead, they may show that, as in the standard model of monopolistic competition, monopoly profits may be dissipated by the fixed costs of entry. Alternatively, as Salinger's results suggest, much of the monopoly rents earned in product markets may be captured by workers rather than shareholders. ${ }^{13}$ Consideration of this issue is deferred until after we examine evidence on labor market rents.

\section{The Interindustry Wage Structure}

Observers of the labor market have long noted that large, systematic wage differences exist among industries even for workers who have similar observed characteristics and work in the same well-defined job classification in the same locality. In a classic 1950 study, Slichter examined the average hourly earnings of unskilled and skilled male workers in manufacturing between 1923 and $1946 .{ }^{14}$ Slichter was struck by the size of industry wage differences for unskilled laborers and the persistence over time of the wage structure. He found that industry average wages for unskilled workers were strongly positively correlated with industry value added per worker and profit margins and negatively correlated with the ratio of payroll to sales. He also found that the pattern of industry wage differences was similar for skilled and unskilled workers. Slichter concluded that though differences in labor quality explained part of interindustry wage differences, managerial discretion that produces "liberal wage policies" where ability to pay is high had a strong influence. Many other researchers in this period reached similar conclusions: that product market characteristics greatly affected wage levels in a way not entirely consistent with a standard competitive labor market model. ${ }^{15}$

13. Michael A. Salinger, "Tobin's q, Unionization, and the Concentration-Profits Relationship,' Rand Journal of Economics, vol. 15 (Summer 1984), pp. 159-70.

14. Sumner H. Slichter, "Notes on the Structure of Wages,"' Review of Economics and Statistics, vol. 32 (February 1950), pp. 80-91.

15. See, for example, Lloyd G. Reynolds, The Structure of Labor Markets: Wages and Labor Mobility in Theory and Practice (Harper and Brothers, 1951); and John T. Dunlop, "'The Task of Contemporary Wage Theory,' in John T. Dunlop, ed., The Theory of Wage Determination, Proceedings of a Conference held by the International Economic 
Several recent studies have further documented large and persistent wage differentials among industries, even after controlling for a wide variety of worker and job characteristics in large individual-level data sets. ${ }^{16}$ Here we summarize the available evidence and present new evidence on the interindustry wage structure.

\section{The Magnitude of Interindustry Wage Differences}

To analyze industry wage differences in the United States, we used cross-sectional data on individuals from the 1984 Current Population Surveys (CPS). We combined all twelve monthly surveys from 1984 so as to generate a sample large enough to estimate accurately wage differentials for detailed industry categories. ${ }^{17}$ Our sample consists of private sector, nonagricultural employees from 16 to 75 years of age. The earnings variable is usual weekly earnings divided by usual weekly hours. ${ }^{18} \mathrm{We}$ normalize the estimated wage differentials as deviations from the (employment-weighted) mean differential.

The first column in table 2 reports the proportionate difference in wages between the average worker in a given two-digit industry and the average worker in all industries. The second column reports the normalized industry wage differences after controlling for years of education, experience (age - years of education - 6), occupation, gender, race, marital status, SMSA (standard metropolitan statistical area)

Association (London: Macmillan, 1957), pp. 3-27. See also Melvin W. Reder, "Wage Differentials: Theory and Measurement,"' in Aspects of Labor Economics, a Conference of the Universities-National Bureau Committee for Economic Research (Princeton University Press, 1962), pp. 257-317, for an attempt to reconcile the findings of these early studies with a textbook competitive labor market model.

16. See, for example, William T. Dickens and Lawrence F. Katz, "Inter-Industry Wage Differences and Industry Characteristics, ' in Kevin Lang and Jonathan S. Leonard, eds., Unemployment and the Structure of Labor Markets (Basil Blackwell, 1987), pp. 48-89; Alan B. Krueger and Lawrence H. Summers, "Efficiency Wages and the InterIndustry Wage Structure," Econometrica, vol. 56 (March 1988), pp. 259-93; and Kevin M. Murphy and Robert H. Topel, "Unemployment, Risk, and Earnings: Testing for Equalizing Wage Differences in the Labor Market," in Lang and Leonard, eds., Unemployment and the Structure of Labor Markets, pp. 103-40.

17. Although the Current Population Surveys are partly a panel data set, only people in outgoing rotation groups are asked about earnings. Further, people exit the sample only once a year. Thus all observations reflect unique individuals.

18. We eliminated employees who reported earning less than $\$ 1.00$ an hour or more than $\$ 250$ an hour. 
Table 2. Estimated Natural Log Wage Differentials between Workers in Selected and All U.S. Industries, 1984

\begin{tabular}{|c|c|c|c|c|}
\hline \multirow[b]{2}{*}{ Industry ${ }^{\mathrm{b}}$} & \multicolumn{4}{|c|}{ Industries } \\
\hline & $\begin{array}{c}\text { All, without } \\
\text { controls } \\
\text { (1) }\end{array}$ & $\begin{array}{l}\text { All, with } \\
\text { controls } \\
\text { (2) }\end{array}$ & $\begin{array}{c}\text { All, total } \\
\text { compensation } \\
\text { with controls } \\
\text { (3) }\end{array}$ & $\begin{array}{l}\text { Nonunion, } \\
\text { with } \\
\text { controls } \\
\text { (4) }\end{array}$ \\
\hline Mining & 0.411 & 0.267 & 0.277 & 0.269 \\
\hline Construction & 0.181 & 0.120 & 0.106 & 0.061 \\
\hline Lumber & -0.102 & -0.046 & -0.011 & -0.009 \\
\hline Furniture & -0.107 & -0.042 & -0.023 & -0.004 \\
\hline Stone, clay, glass & 0.097 & 0.066 & 0.117 & 0.057 \\
\hline Primary metals & 0.280 & 0.164 & 0.262 & 0.156 \\
\hline Fabricated metals & 0.138 & 0.072 & 0.131 & 0.071 \\
\hline Machinery, except electrical & 0.311 & 0.146 & 0.182 & 0.170 \\
\hline Electrical machinery & 0.188 & 0.083 & 0.110 & 0.099 \\
\hline Transportation equipment & 0.388 & 0.207 & 0.282 & 0.187 \\
\hline Instruments & 0.258 & 0.105 & 0.132 & 0.147 \\
\hline Miscellaneous manufacturing & -0.087 & -0.063 & -0.044 & -0.022 \\
\hline Food & 0.051 & 0.050 & 0.101 & 0.035 \\
\hline Tobacco & 0.260 & 0.240 & 0.426 & 0.219 \\
\hline Textiles & -0.134 & -0.004 & 0.007 & 0.045 \\
\hline Apparel & -0.347 & -0.152 & -0.150 & -0.113 \\
\hline Paper & 0.234 & 0.164 & 0.199 & 0.140 \\
\hline Printing & 0.067 & 0.027 & 0.029 & 0.023 \\
\hline Chemical & 0.354 & 0.188 & 0.231 & 0.214 \\
\hline Petroleum & 0.501 & 0.286 & 0.533 & 0.280 \\
\hline Rubber & 0.103 & 0.093 & 0.136 & 0.121 \\
\hline Leather & -0.282 & -0.137 & -0.118 & -0.097 \\
\hline Transportation & 0.225 & 0.157 & 0.184 & 0.077 \\
\hline Communications & 0.400 & 0.250 & 0.371 & 0.213 \\
\hline Public utilities & 0.443 & 0.267 & 0.342 & 0.265 \\
\hline
\end{tabular}

status, region, full-time work, and student status, and allowing many of the coefficients to differ for males and females. Controlling for available worker characteristics has little effect on the rankings of different industries; the correlation of the industry wage differentials estimated with and without controls is 0.95 . This finding suggests that comparisons of average industry wages over time and across countries may be useful, since controls are unlikely to change one's inferences about the relative rankings of industries in the wage structure.

The controls do substantially reduce the estimated interindustry dispersion of wages. The standard deviation of the estimated wage 
Table 2 (continued)

\begin{tabular}{|c|c|c|c|c|}
\hline \multirow[b]{2}{*}{ Industry $^{\mathrm{b}}$} & \multicolumn{4}{|c|}{ Industries } \\
\hline & $\begin{array}{l}\text { All, without } \\
\text { controls } \\
\text { (1) }\end{array}$ & $\begin{array}{c}\text { All, with } \\
\text { controls } \\
\text { (2) }\end{array}$ & $\begin{array}{c}\text { All, total } \\
\text { compensation } \\
\text { with controls } \\
\text { (3) }\end{array}$ & $\begin{array}{l}\text { Nonunion, } \\
\text { with } \\
\text { controls } \\
\text { (4) }\end{array}$ \\
\hline Wholesale trade & 0.123 & 0.035 & 0.011 & 0.050 \\
\hline Eating and drinking & -0.592 & -0.251 & -0.283 & -0.237 \\
\hline Other retail trade & -0.251 & -0.140 & -0.173 & -0.144 \\
\hline Banking & 0.110 & 0.050 & 0.077 & 0.062 \\
\hline Insurance & 0.121 & 0.050 & 0.052 & 0.067 \\
\hline Private household & -0.808 & -0.356 & -0.508 & -0.331 \\
\hline Business services & -0.002 & -0.021 & -0.053 & -0.008 \\
\hline Repair services & -0.063 & -0.091 & -0.123 & -0.064 \\
\hline Personal services & -0.371 & -0.182 & -0.223 & -0.167 \\
\hline Entertainment & -0.176 & -0.125 & -0.149 & -0.146 \\
\hline Medical services & -0.160 & -0.038 & -0.036 & -0.018 \\
\hline Hospitals & 0.115 & 0.073 & 0.075 & 0.081 \\
\hline Welfare services & -0.191 & -0.243 & -0.328 & -0.242 \\
\hline Education services & -0.011 & -0.171 & -0.194 & -0.176 \\
\hline Professional services & 0.276 & 0.095 & 0.054 & 0.101 \\
\hline Sample size & 116,387 & 116,387 & 116,387 & 95,793 \\
\hline $\begin{array}{l}\text { Weighted adjusted standard } \\
\text { deviation of differentials }\end{array}$ & 0.284 & 0.151 & 0.193 & 0.146 \\
\hline
\end{tabular}

Source: Authors' calculations using the Full Year 1984 CPS.

a. In all cases the standard errors are between 0.006 and 0.027 except for tobacco, which has standard errors that range from 0.039 to 0.049 .

b. Two-digit CIC industries.

c. Controls comprise education and its square; experience (age - education - 6), its square, and its cube; eight occupation dummies; a female dummy; a race dummy; an SMSA dummy; three region dummies; a full-time work dummy; full- and part-time student dummies; interactions of the female dummy with marriage, education, education squared, and the experience variables; and a constant. Each column was estimated from a separate cross-sectional regression.

d. Weights are employment shares for the entire sample (union and nonunion).

differentials falls from 28 percent without controls to 15 percent when controls are added. ${ }^{19}$ As will be discussed further, most of this decline is attributable to holding broad occupational category, region, race, and sex constant. Industry affiliation has a large effect on relative wages even when observed differences in occupation, human capital variables, and demographic background are taken into account. Industry differ-

19. To summarize the overall variability in wages across industries, we focus on the employment-weighted standard deviation of industry wage differentials. We present standard deviations of the estimated differentials that have been adjusted for OLS sampling error using the procedure described in Krueger and Summers, "Efficiency Wages." The adjustments for sampling error are minuscule (on the order of 0.001 to 0.005 ) in all cases. 
entials (with controls) range from a high of 29 percent above the mean in petroleum to 36 percent below the mean in private household services. Durable goods manufacturing, mining, and chemicals pay wages well above those for workers in retail trade and service industries, all else constant. Substantial wage differentials are also apparent within the traded-goods (manufacturing) sector; the standard deviation of the adjusted industry wage differentials in the manufacturing sector is 11 percent.

One explanation is that these differentials largely serve to offset differences in nonwage compensation. Using our data, we can control for one nonwage aspect of compensation, fringe benefits, which account for as much as 50 percent of compensation in some industries. To adjust for variation in fringes across industries, we multiplied our CPS hourly wage data for each worker in the sample by the ratio of total labor costs to wages in the corresponding industry. ${ }^{20}$ The third column of table 2 presents estimates of industry wage differentials with the dependent variable adjusted to reflect both wage and nonwage compensation. The estimated standard deviation of industry differentials actually increases by more than one-fourth, from 15.1 to 19.3 percent. Thus the consideration of fringe benefits reinforces, rather than reduces, differences in industry compensation.

Another possible explanation for these large wage differentials is that they represent skill-mix differences among industries that remain even after we control for a person's broad (one-digit) occupational category. We tested this explanation by examining interindustry differentials for more refined (three-digit) occupational categories. Table 3 shows adjusted interindustry wage differentials for managers and administrators not elsewhere classified, secretaries, janitors, and laborers. ${ }^{21}$ Even at this level of occupational detail the differences are large, with standard deviation of industry differentials ranging from 9.2 percent for secretaries to 16.8 percent for janitors. ${ }^{22}$ Furthermore, many studies of local labor markets have found large wage differentials among industries for nar-

20. The industry labor cost and wage data are reported in the national income and product accounts (NIPA) and were previously used in Krueger and Summers, "Efficiency Wages.",

21. These occupations represent the following three-digit 1980 (census occupation code) occupation categories: 19 (managers and administrators, n.e.c.), 313 (secretaries), 453 (janitors), 863-89 (laborers).

22. William T. Dickens and Lawrence F. Katz, "Further Notes on the Inter-Industry Wage Structure,"' Harvard University, August 1988, find in an examination of nonunion 
rowly defined job categories in the same locality. Dunlop found that wage differences for unionized truck drivers doing similar work in Boston in July 1951 ranged from $\$ 1.20$ an hour in the wholesale laundry industry to $\$ 2.25$ an hour in the magazine industry. ${ }^{23}$ These differences followed closely the overall industry wage pattern in Boston. A glance at a recent Area Wage Survey for the Boston Metropolitan Area reveals many similar patterns: large wage differentials exist even among positions with little unionization in which work is classified as being "routine and repetitive" and done "under close supervision." For example, Key Entry Operators I in Boston in August 1987 were paid a median salary of $\$ 445$ in transportation and utilities, \$300 in manufacturing, and \$269 in nonmanufacturing. ${ }^{24}$

Discussions of industry wage differences frequently emphasize the importance of unions in wage setting. But the inclusion of union membership and union coverage dummy variables in the specification reported in the second column of table 2 has little effect on the estimated industry differentials. The standard deviation of the differentials falls from 15.1 to 14.6 percent. Since unions are likely to have different effects on wages in industries with different product market structures and costs of strikes, a better approach is to assess the importance of industry differentials for a sample containing only nonunion workers. ${ }^{25}$ As column 4 in table 2 shows, the industry wage premiums are quite substantial for nonunion workers. We also estimated differentials for the union workers in our sample and found that the standard deviation of the differentials for both union and nonunion workers is 14.6 percent; the raw correlation of the differentials for the union and nonunion samples is 0.78 . Thus the process generating relative wages in industries appears to be much the same in the union and nonunion sectors. ${ }^{26}$

workers in the fifteen three-digit census occupations with large enough samples in the CPS to precisely estimate industry differentials that substantial differentials are apparent even after the inclusion of extensive control variables. The median standard deviation of log industry differentials is 0.106 .

23. Dunlop, "Task of Contemporary Wage Theory," p. 21.

24. U.S. Bureau of Labor Statistics, Area Wage Survey Boston, Massachusetts, Metropolitan Area, August 1987, Bulletin 3040-34 (Department of Labor, November 1987), pp. 3-12, 45 .

25. The nonunion sample consists of workers not covered by collective bargaining agreements.

26. Furthermore, we later present evidence that many regularities in the industry wage structure often attributed to union effects on wages actually predate the rise of extensive unionism in the United States. 
Table 3. Estimated Natural Log Wage Differentials for Four Occupational Categories in U.S. Industries, 1984

\begin{tabular}{lrrrr}
\hline & \multicolumn{3}{c}{ Occupation, with controls $^{\mathrm{a}}$} \\
\cline { 2 - 5 } \multicolumn{1}{c}{ Industry } & $\begin{array}{c}\text { Managers } \\
\text { (n.e.c.) }\end{array}$ & Janitors & Secretaries & Laborers \\
\hline Mining & 0.220 & 0.209 & 0.229 & 0.276 \\
Construction & 0.094 & 0.086 & -0.042 & 0.118 \\
Lumber & 0.024 & -0.115 & -0.107 & -0.063 \\
Furniture & -0.139 & -0.014 & -0.038 & -0.113 \\
Stone, clay, and glass & 0.012 & 0.311 & -0.019 & 0.082 \\
Primary metals & 0.073 & 0.186 & 0.088 & 0.203 \\
Fabricated metals & 0.094 & 0.122 & -0.001 & 0.080 \\
Machinery, except electrical & 0.213 & 0.001 & 0.086 & 0.105 \\
Electrical machinery & 0.126 & 0.163 & 0.086 & 0.104 \\
Transportation equipment & 0.096 & 0.343 & 0.148 & 0.211 \\
Instruments & 0.146 & 0.161 & 0.066 & 0.171 \\
Miscellaneous manufacturing & 0.153 & -0.222 & -0.037 & -0.173 \\
Food & 0.024 & 0.142 & 0.060 & 0.050 \\
Tobacco & 0.354 & 0.686 & 0.451 & 0.241 \\
Textiles & 0.095 & -0.016 & -0.096 & 0.027 \\
Apparel & 0.061 & -0.206 & -0.107 & -0.128 \\
Paper & 0.068 & 0.280 & 0.190 & 0.167 \\
Printing & 0.044 & -0.055 & 0.018 & 0.048 \\
Chemical & 0.258 & 0.196 & 0.164 & 0.127 \\
Petroleum & 0.155 & 0.377 & 0.190 & 0.297 \\
Rubber & 0.136 & 0.140 & 0.267 & 0.125 \\
Leather & -0.192 & -0.084 & -0.146 & -0.139 \\
Transportation & 0.048 & 0.135 & 0.001 & 0.267 \\
Communications & 0.271 & 0.314 & 0.185 & 0.201 \\
Public utilities & 0.241 & 0.252 & 0.184 & 0.192 \\
& & & &
\end{tabular}

\section{Regularities in the Interindustry Wage Structure}

As several studies have shown, industry wage differences appear to be quite stable across time and space. Krueger and Summers found that during the 1900-84 period the correlation between relative wages in nine major industries was 0.62 and during $1970-84$ it was $0.91 .{ }^{27}$ They further documented that the relative rankings of industry average wages in detailed manufacturing industries were also extremely stable over time.

27. Alan B. Krueger and Lawrence H. Summers, "Reflections on the Inter-Industry Wage Structure,' in Lang and Leonard, eds., Unemployment and the Structure of Labor Markets, pp. 17-47. 
Table 3 (continued)

\begin{tabular}{|c|c|c|c|c|}
\hline \multirow[b]{2}{*}{ Industry } & \multicolumn{4}{|c|}{ Occupation, with controls ${ }^{\mathrm{a}}$} \\
\hline & $\begin{array}{l}\text { Managers } \\
(\text { n.e.c. })^{\mathrm{b}}\end{array}$ & Janitors & Secretaries & Laborers \\
\hline Wholesale trade & 0.034 & 0.055 & 0.006 & -0.007 \\
\hline Eating and drinking & -0.315 & -0.210 & -0.060 & -0.087 \\
\hline Other retail trade & -0.125 & -0.160 & -0.100 & -0.073 \\
\hline Banking & 0.182 & -0.065 & 0.055 & -0.515 \\
\hline Insurance & 0.084 & -0.091 & -0.020 & 0.145 \\
\hline Private household & -0.392 & 0.150 & 0.124 & 0.258 \\
\hline Business services & 0.002 & -0.101 & -0.023 & -0.133 \\
\hline Repair services & -0.208 & -0.188 & 0.085 & -0.155 \\
\hline Personal services & -0.343 & -0.134 & -0.117 & -0.156 \\
\hline Entertainment & -0.237 & -0.123 & -0.036 & 0.098 \\
\hline Medical services & -0.062 & -0.086 & -0.040 & -0.282 \\
\hline Hospitals & 0.092 & -0.070 & -0.014 & 0.126 \\
\hline Welfare services & -0.101 & -0.160 & -0.127 & -0.156 \\
\hline Education services & -0.169 & -0.125 & -0.148 & -0.395 \\
\hline Professional services & 0.090 & 0.435 & 0.096 & 0.158 \\
\hline Sample size & 6,117 & 2,154 & 4,722 & 6,056 \\
\hline $\begin{array}{l}\text { Weighted adjusted standard } \\
\text { deviation of differentials }\end{array}$ & 0.153 & 0.168 & 0.092 & 0.160 \\
\hline
\end{tabular}

Source: Authors' calculations using the Full Year 1984 CPS.

a. Controls include education and its square; experience (age - education - 6), its square, and its cube; a female dummy; a race dummy; an SMSA dummy; three region dummies; a full-time work dummy; full- and part-time student dummies; interactions of the female dummy with marriage, education, education squared, and the experience variables; and a constant. Each column was estimated from a separate cross-sectional regression.

b. Not elsewhere classified.

c. Weights are employment shares for the entire sample (all occupations).

Figure 1 plots industry wage differentials for twenty two-digit manufacturing industries estimated from the May 1974 CPS against analogous differentials estimated from the May 1984 CPS. ${ }^{28}$ The figure shows that despite widespread concern about the impact of trade on affected industries, the industry wage structure in manufacturing has been very stable over the last decade. In a recent study Freeman and Katz examined the effects of import competition on relative industry wages in U.S. manufacturing and found that a 10 percent decrease in industry revenues from increased import penetration reduces an industry's relative wage for production workers by only 0.5 percent. ${ }^{29}$

28. The estimates are taken from table 2 of Krueger and Summers, "Efficiency Wages."

29. Richard B. Freeman and Lawrence F. Katz, "Industrial Wage and Employment Determination in an Open Economy," in Richard B. Freeman, ed., Immigration, Trade, 
Figure 1. U.S. Wage Structure, 1974 versus 1984

Ln wage premiums for manufacturing industries

1984

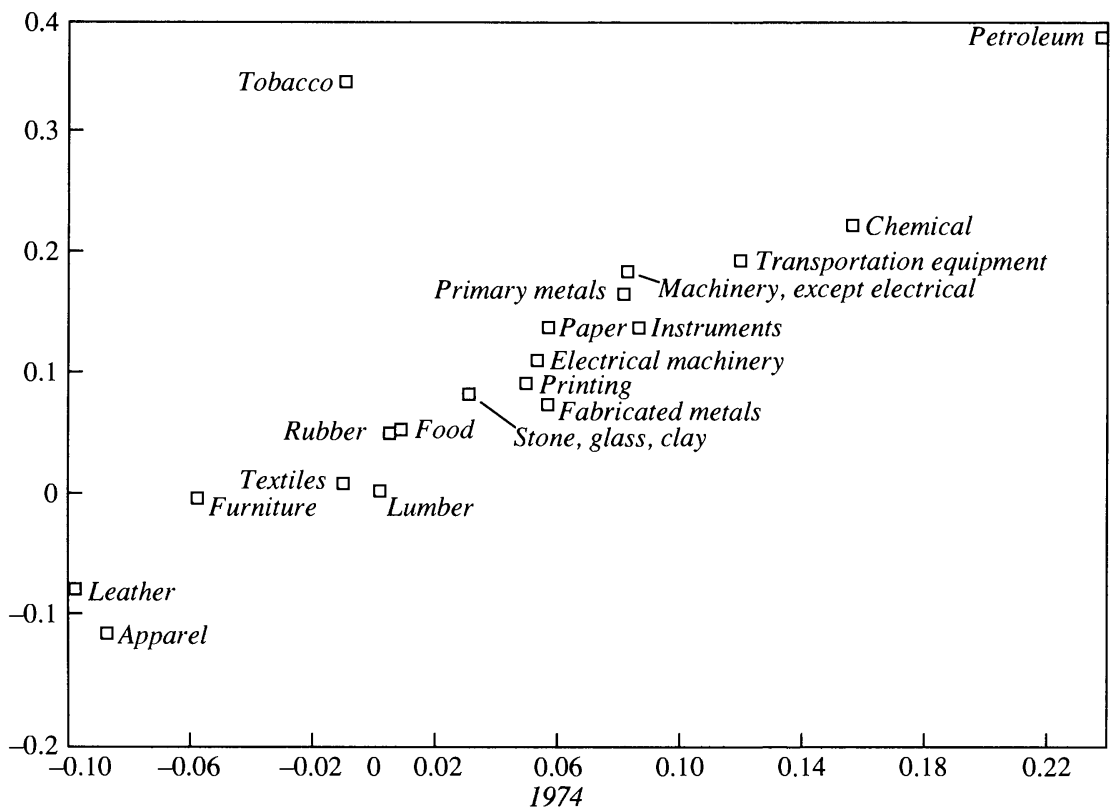

Source: Alan B. Krueger and Lawrence H. Summers, "Efficiency Wages and the Inter-Industry Wage Structure," Econometrica, vol. 56 (March 1988), p. 265. These are ln wage differentials based on standard In earnings regressions with two-digit industry dummies using the May 1974 and May 1984 Current Population Surveys.

Industry wage patterns are remarkably similar among countries with diverse labor market institutions. As we show in table 4, in 1983 relative wages in manufacturing among nine countries were much alike. By using a single occupational group (operatives), we can control for skill-mix differences across countries. The cross-country correlations of relative wages are high, typically between 0.6 and $0.9 .{ }^{30}$ For example, as shown

and the Labor Market (University of Chicago Press, forthcoming). In contrast, Kevin Murphy and Finis Welch, "Wage Differentials in the 1980s: The Role of International Trade," paper presented at the Mont Pelerin Society General Meeting, September 9, 1988, document that the earnings of "skilled" (college-educated) workers rose dramatically relative to those of less-educated workers from 1979 to 1985 . It seems somewhat remarkable that in a period of dramatic changes in skill differentials, the industry wage structure remained fairly stable.

30. Krueger and Summers, "Reflections on the Inter-Industry Wage Structure," also find strong positive correlations in relative average industry wages among a larger group of countries. 


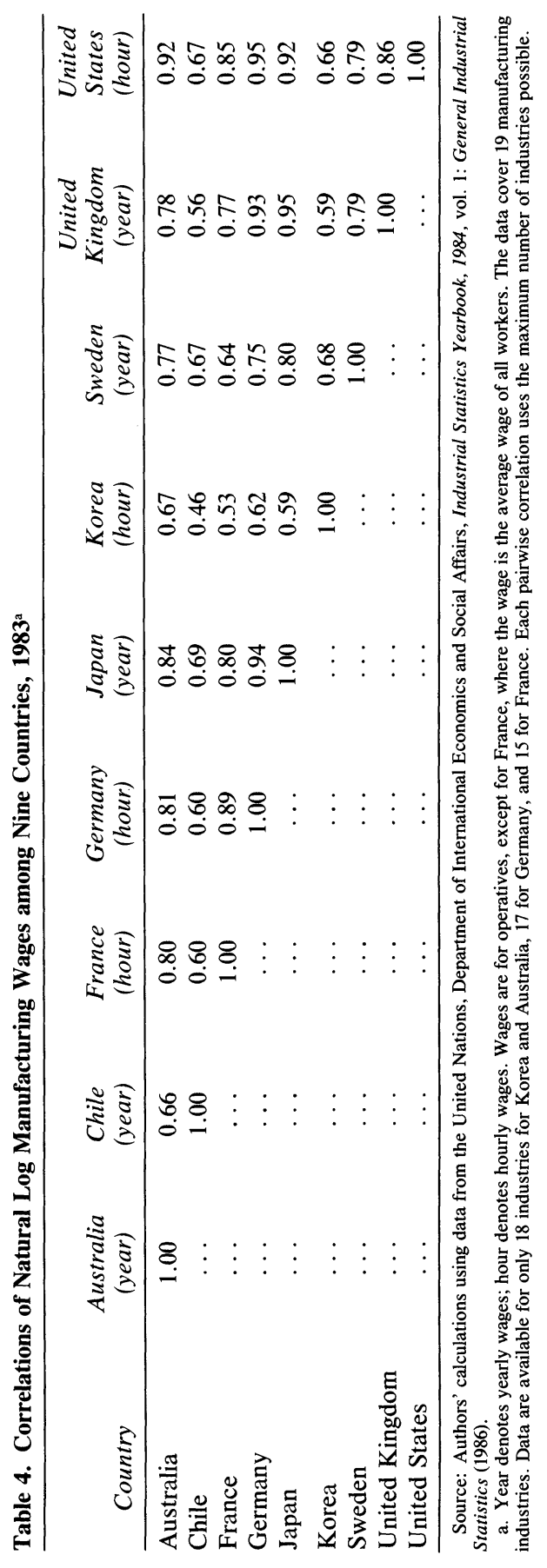


Figure 2. Wage Structure, United States versus Japan, 1983 $^{\mathrm{a}}$

Ln wages of operatives ${ }^{b}$

United States

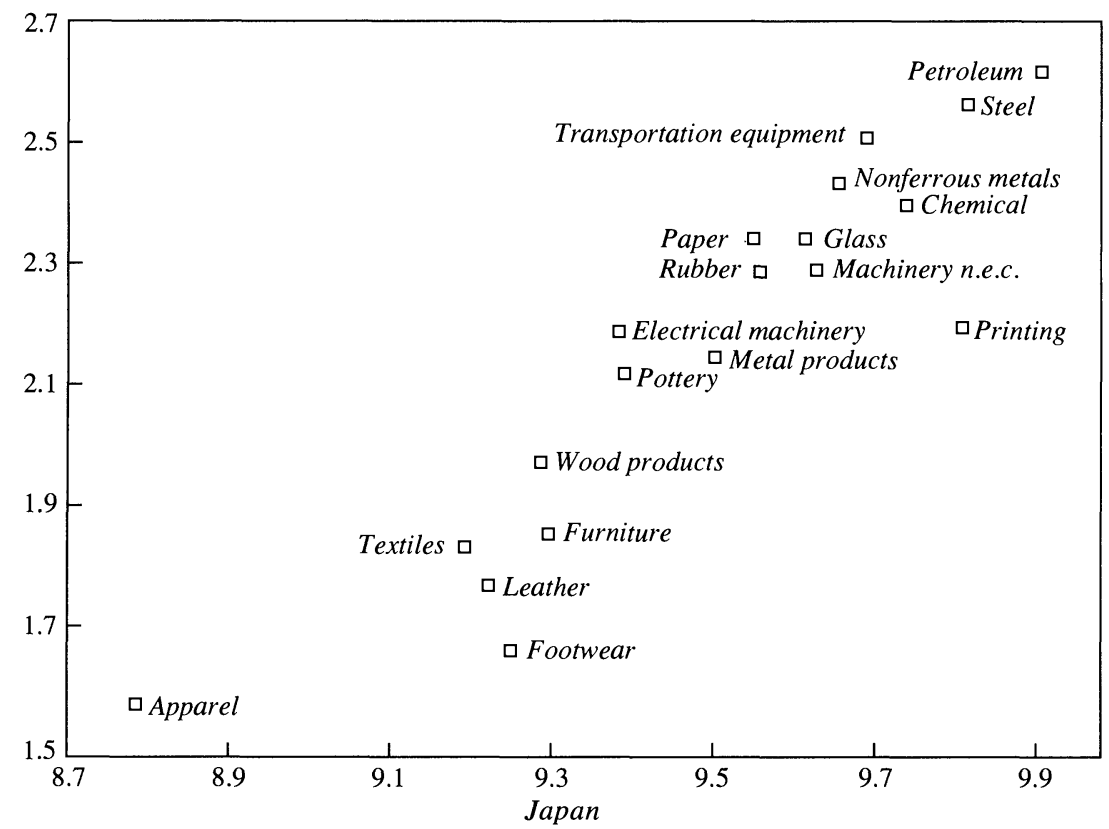

Source: Authors' calculations using data from United Nations, Department of International Economics and Social Affairs, Industrial Statistics Yearbook, 1984, vol. 1: General Industrial Statistics (1986), pp. 313, 584.

a. International standard industrial classification industries.

b. Annual earnings for Japan; hourly earnings for the United States.

in the table, in 1983 the correlation between the relative wages of operatives in the United States and Japan was 0.92. We illustrate this similarity in the wage structures of the United States and Japan in figure 2. The stability in differentials across time periods and countries strongly suggests that these wage differences result from factors fundamental to the operation of industrial economies and are not the artifact of particular collective bargaining systems or government interventions in the labor market.

The industry wage structure also seems to be similar for different types of workers. In industries in which one occupation is highly paid, all occupations tend to be highly paid. This is illustrated by the similarity in the differentials for the four occupational groups examined in table 3. The raw correlations of the industry differentials for these four disparate 
occupational groups range from 0.49 between managers and janitors to 0.85 between laborers and janitors. In a more extensive examination of this issue, Dickens and Katz find a remarkable similarity in the interindustry wage structure for all one-digit occupational groups, with a median correlation of 0.78 . Furthermore, Krueger and Summers find that the pattern of differentials is about the same for young and old workers and for workers with short and long job tenures. The similar patterns for different types of workers in recent U.S. data mimic the earlier findings of Slichter for $1939 .{ }^{31}$

\section{Competitive Explanations for Interindustry Wage Differentials}

The competitive labor market model offers two types of explanation for persistent interindustry wage differentials. These differentials may compensate for nonpecuniary differences in job attributes, or they may reflect differences in unmeasured labor quality. If compensating differentials and unobserved ability adequately explain the bulk of measured industry wage differences, then the presence of large industry wage differentials should not be an important consideration in evaluating industrial policies. Here we examine the importance of these two expenditures.

Compensating differentials. For several reasons, interindustry wage differences are not easily explained by compensating differentials. First, Krueger and Summers find that the inclusion of controls for observable differences in working conditions tends to increase rather than decrease estimates of the extent of interindustry wage variation. ${ }^{32}$ Furthermore, as seen in table 2 , the consideration of fringe benefits leads to substantially larger estimates of differences in industry compensation. Thus the consideration of observed nonwage compensation exacerbates the industry differentials.

31. William T. Dickens and Lawrence F. Katz, "Inter-Industry Wage Differences and Theories of Wage Determination," Working Paper 2271 (Cambridge, Mass.: National Bureau of Economic Research, June 1987), p. 9; Krueger and Summers, "Efficiency Wages,"' p. 277; and Slichter, "Notes on the Structure of Wages," p. 83.

32. Krueger and Summers, "Efficiency Wages," pp. 273-75, find that the inclusion of controls for weekly hours, commute time, and shift variables, variables indicating the presence of danger on the job and whether working conditions are pleasant, and a variable indicating extent of choice over overtime actually increases the standard deviation of onedigit industry differentials in the 1977 Quality of Employment Survey from 0.113 to 0.118. 
Second, the strong correlation in interindustry wage differences across occupations is also difficult to explain through equalizing differences, since it is unlikely that whenever working conditions are poor for production workers, they are also poor for managers, secretaries, and salesmen. Third, we will present evidence showing that there is a strong negative correlation between industry wage differences and quit rates and that high-wage industries attract a greater number of job applicants per opening than low-wage industries do. This evidence strongly suggests that workers in high-wage industries earn rents even though it is potentially consistent with industry differentials reflecting some type of labor quality that is correlated with worker stability.

Unmeasured labor quality. Alternatively, these wage differences might be explained by differences in workers' productive abilities not captured by the variables available in individual-level data sets. But though unobserved quality differences almost certainly account for much of the variation in the wages that workers with similar observed characteristics receive, this does not necessarily imply that differences in the average wage paid in different industries are the result of differences in the average level of unobserved ability.

A first approach to determining whether it is reasonable to assume that industry wage differentials can largely be accounted for by the sorting of workers across industries on the basis of unmeasured aspects of labor quality is to look at how observed measures of labor quality such as education differ across industries. A striking aspect of the estimated industry differentials presented in table 2 is that the effect of the controls on the estimated differentials - the industry wage differential without controls (column 1) minus the industry wage differential with controls (column 2)-and the industry wage differentials with controls are highly positively correlated. ${ }^{33}$ This finding invites the interpretation that our estimates of significant wage differentials may be inflated because of our inability to control statistically for the effects of unmeasured labor quality.

Although that interpretation has validity, it cannot, we believe, entirely explain our results. As table 5 illustrates, most of the effect of

33. Let $w=$ wage differentials without controls, $w^{c}=$ the wage differential with controls, and $e^{c}=w-w^{c}=$ the effect of the controls; $w^{c}$ and $e^{c}$ are strongly positively correlated. We are grateful to Charles Schultze for pointing out this especially clear way of looking at the possibility that unmeasured labor quality may be responsible for a substantial part of the estimated differentials with controls. 
Table 5. Industry Wage Differentials and Alternative Sets of Controls, 1984

Weighted adjusted standard deviation of industry

Controls differentials

1. None 0.284

2. Row 1 plus three region dummies, an SMSA dummy, a race dummy, a female dummy, and occupation dummies

3. Row 2 plus marital status and married $\times$ female dummies

4. Row 3 plus three experience variables and interactions of each with female

5. Row 4 plus education and its square and interactions of each with female

6. Row 5 plus a full-time dummy and two student status dummies

Source: Authors' calculations using the Full Year 1984 CPS

a. The industry differentials are for the two-digit CIC industries listed in table 2. The sample size is 116,387.

the control variables comes from adding controls for occupation, region, and sex. Once these variables have been controlled, further proxies like education and experience reduce estimated industry wage differentials by only a small amount. That is true even though education and experience have considerable explanatory power in our wage equations. The crucial point is this: though high-wage-premium industries disproportionately employ men and workers in some high-wage occupations, they do not disproportionately employ highly educated or experienced workers by enough to affect significantly estimated industry wage differentials, once other variables are included. If high-wage industries do not rely more heavily on workers with easily observable correlates of ability like education, it seems implausible that they rely disproportionately on workers with substantial unobserved ability. Evidence supporting this judgment comes from Blackburn and Neumark's finding that, once other variables have been controlled, there is actually a negative relationship between an industry's wage and the intelligence quotient of its workers, or their score on a test designed to evaluate their "knowledge of the world of work." ${ }^{34}$ Given the absence of a high degree of industrial sorting on the basis of observed labor quality proxies, a high degree of sorting on unobserved characteristics would be surprising.

Murphy and Topel have developed a statistical procedure for assessing

34. McKinley Blackburn and David Neumark, "Efficiency Wages, Inter-Industry Wage Differentials and the Returns to Ability," University of South Carolina, June 1988. 
the potential importance of unobserved ability in driving industry wage differentials..$^{35}$ They assume that sorting across industries takes place to an equal extent on observed and unobserved abilities. This assumption probably overstates the role of unobserved ability, since one would expect sorting across industries to be better for characteristics that can be easily observed. Murphy and Topel's results lead them to conclude that unobserved ability accounts for the bulk of industry wage differentials. But when their approach is applied to sorting across industries rather than sorting across both industries and occupations for males using our Full Year 1984 CPS sample, the results are less favorable to the unobservable ability hypothesis. ${ }^{36}$ When education is used as the sorting variable, little evidence is found of differences in unobserved ability across industries, since the coefficient on years of schooling in an earnings equation barely changes when industry dummies are added to the specification. However, if marital status (for males) is treated as an ability variable, the results do suggest considerable sorting across industries. One may conclude either that considerations like reliability rather than cognitive skill are important in determining differences in industry wages, or that marital status itself is determined in part by workers' ability to get secure jobs in high-wage industries.

Longitudinal evidence. Longitudinal data that follow individuals as they change industries allow one to control for the effects of unmeasured productive ability on estimates of interindustry wage differentials if one assumes that market assessments of a given individual's ability do not change over time. Four recent studies have used individual-level, longitudinal data sets to examine whether wage changes are systematically related to changes in industry (see table 6).

Using quite different data sets, the studies of Krueger and Summers, Gibbons and Katz, and Blackburn and Neumark all find that when individual workers move between industries, either because of displacement or because of normal labor market processes, their wages change by amounts similar to the industry differentials estimated in crosssectional regressions. The three studies find that workers who move between industries experience a relative wage change of 60 to 100 percent of the amount that would be predicted from a cross-sectional wage

35. Kevin M. Murphy and Robert H. Topel, "Efficiency Wages Reconsidered: Theory and Evidence,"' University of Chicago, May 1987.

36. These results are described more fully in an appendix available from the authors. 
Table 6. Survey of Studies of Interindustry Wage Differentials Using Longitudinal Data

\begin{tabular}{|c|c|c|}
\hline Study & Data and methodology & Results \\
\hline $\begin{array}{l}\text { Krueger and } \\
\text { Summers, } 1988\end{array}$ & $\begin{array}{l}\text { Matched May CPSs for 1974-75, } \\
1977-78 \text {, and 1979-80. Compare one- } \\
\text { digit industry differentials estimated } \\
\text { in a cross section (CS) with controls } \\
\text { to fixed effects (FE) estimates with } \\
\text { an adjustment for industry } \\
\text { misclassifications. }\end{array}$ & $\begin{array}{l}\text { The CS and FE estimates have a } \\
\text { correlation of } 0.96 \text {. The standard } \\
\text { deviations of the CS differentials } \\
\text { and the preferred adjusted FE } \\
\text { industry differentials are both } \\
0.12 \text {. }\end{array}$ \\
\hline
\end{tabular}

Murphy and Topel, 1987

Gibbons and Katz, 1987

Blackburn and Neumark, 1988
Males from matched March CPSs for 1977-83. Estimate first-difference regressions with change in CS industry differential and CS occupation differentials included as covariates. Restrict sample to workers who change industry between two years in sample and are still employed in new industry at interview date. Wage variable is annual earnings divided by weeks worked at all jobs in previous year.

January 1984 Displaced Workers Survey. Estimate first-difference regressions with change in $\mathrm{CS}$ industry differentials and other controls included.

National Longitudinal Study Young Men's Cohort in early part of sample (1966-73) and 1980. Estimate longchange first difference regression with change in CS differential included.
Estimated coefficient on change in CS industry differential is $\mathbf{0 . 3 6}$ in basic wage-change equation and 0.27 when change in percent of union members in industryoccupation cell is added as a covariate.

Estimated coefficient on change in CS industry differential is $\mathbf{0 . 6 3}$ for full sample, $\mathbf{0 . 7 3}$ for those displaced at least two years, 0.74 for males, and 0.88 for males displaced at least two years.

Estimated coefficient on change in industry differential ranges from 0.64 to 0.70 depending on the exact sample used.

Sources: Alan B. Krueger and Lawrence H. Summers, "Efficiency Wages and the Inter-Industry Wage Structure," Econometrica, vol. 56 (March 1988), pp. 259-94; Kevin M. Murphy and Robert H. Topel, "Efficiency Wages Reconsidered: Theory and Evidence," University of Chicago and NBER, May 1987; Robert Gibbons and Lawrence Katz, "Learning, Mobility and Inter-Industry Wage Differences," Massachusetts Institute of Technology, December 1987; and McKinley Blackburn and David Neumark, "Efficiency Wages, Inter-Industry Wage Differentials and the Return to Ability," University of South Carolina, June 1988.

equation. Furthermore, the results are similar when only displaced workers who have had at least two years to find a reasonable new match are analyzed. That is significant because the selection processes generating observed movements are very different in the several data sets, making it unlikely that the results can be explained by changing market assessments of individuals' ability.

All three of these studies use point-in-time wage data, where the wage variable is wage on the current job and the industry variable is the industry on the current job. In contrast to those results, Murphy and 
Topel find that industry switchers receive only 27 to 36 percent of the cross-sectional differential. One possible reason for this much lower effect is that Murphy and Topel use matched March CPS data and rely on only a worker's primary industry affiliation for the previous year and the workers' aggregate earnings across all jobs held during that year. Thus the two annual earnings measures used to construct the wage variable for the wage change regression are likely to contain earnings from the same job, which probably leads to a downward-biased estimate of the coefficient on the change in a worker's industry differential.

Overall, the findings of longitudinal studies cast some doubt on the hypothesis that measured interindustry wage differences are largely attributable to time-invariant, unobserved productive ability. But the possibility exists that interindustry mobility may at least partly reflect changes in market perceptions of worker quality. Think, for example, of those who move between minor and major league baseball. To pin down industry effects in a fully satisfactory fashion, one would need data in which industry changes were exogenous or at least not associated with any new perceptions of worker ability.

Data from the Displaced Worker Supplements (January 1984) to the CPS come very close to fulfilling this criterion. Workers enter the DWS only if they were displaced from a job in the five years before the survey because of a plant closing, an employer going out of business, or a permanent layoff. Workers who were discharged from a job for cause or who quit a job are explicitly excluded from the DWS. Gibbons and Katz have used the January 1984 DWS sample to examine the extent to which "exogenously" displaced workers retain their industry wage premiums. ${ }^{37}$ If our estimated industry wage differentials largely reflected unmeasured differences in worker quality, one would expect to find that displaced workers from high-wage industries would tend to maintain their wage differentials over those displaced from low-wage industries once these displaced workers had a reasonable amount of time to locate suitable new jobs. Instead, Gibbons and Katz find that the industries to which workers move have a substantial effect on their reemployment wages, whereas the industries from which they come have a smaller impact. Displaced workers receive only 12 to 40 percent of their old

37. Robert Gibbons and Lawrence Katz, "Learning, Mobility and Inter-Industry Wage Differences,"’ MIT, December 1987. 
industry wage premiums when they are reemployed, even when the sample is restricted to those who have had two years since displacement to find new matches.

One can marshal further argument against the hypothesis that unobserved worker ability is the major factor contributing to industry wage differentials. As we have already stressed, there is a very high correlation in the wage structure across industries for different occupational groups. But there is not a similarly high correlation in educational attainment across industries for different occupational groups. ${ }^{38}$ One explanation may be that wages are correlated with the extent of the rents an industry earns.

\section{Noncompetitive Explanations for Interindustry Wage Differentials}

If industry wage differentials really reflect labor rents rather than differences in labor quality or in compensating differentials, we would expect industries with high-wage differentials to have relatively low quit rates and to face relatively long queues of job applicants. In this section we examine evidence related to these two predictions of noncompetitive explanations for industry differentials.

We first examine the relation between industry wage premiums and the quit rate in seventy-four three-digit (census industry code, CIC) manufacturing industries. A negative relationship between industry average wages and quit rates is well established in the literature. ${ }^{39} \mathrm{We}$ find that this negative relationship is driven by a negative correlation between the industry wage premium and the quit rate, not by measured worker characteristics that are correlated with both high wages and low quit rates. Our measure of the industry wage premium is the industry wage differential from a natural log earnings regression on our Full Year 1984 CPS sample that contains a dummy variable for each three-digit manufacturing industry as well as a full set of controls for location and worker characteristics. ${ }^{40}$ The industry quit rate and ln average hourly

38. Dickens and Katz, "Further Notes," pp. 10-11.

39. See, for example, John H. Pencavel, An Analysis of the Quit Rate in American Manufacturing Industry (Princeton University, Industrial Relations Section, 1970).

40. The controls comprise six age dummies; six age-sex interaction terms; two-digit industry dummies for industries outside of manufacturing; education and its square; eight occupation dummies; a female dummy; a race dummy; an SMSA dummy; three region 
Table 7. Quit Rates and Industry Wage Differentials in Seventy-Four U.S. Manufacturing Industries ${ }^{\mathrm{a}}$

Dependent variable: quits per 100 employees

\begin{tabular}{|c|c|c|c|}
\hline \multirow[b]{2}{*}{ Item } & \multicolumn{3}{|c|}{$\begin{array}{c}\text { Dependent variable: quits per } 100 \text { employees } \\
\text { per month in } 1981^{\mathrm{b}}\end{array}$} \\
\hline & Mean & (1) & $(2)$ \\
\hline Ln wage premium & $\begin{array}{c}0.23 \\
(0.11)\end{array}$ & $\begin{array}{c}-4.26 \\
(1.42)\end{array}$ & $\begin{array}{c}-3.71 \\
(0.95)\end{array}$ \\
\hline Ln average hourly wage & $\begin{array}{c}2.06 \\
(0.21)\end{array}$ & $\begin{array}{c}-0.65 \\
(0.76)\end{array}$ & $\ldots$ \\
\hline Fraction union members & $\begin{array}{c}0.27 \\
(0.14)\end{array}$ & $\ldots$ & $\begin{array}{r}-0.03 \\
(0.56)\end{array}$ \\
\hline Average years of schooling & $\begin{array}{l}12.02 \\
(0.82)\end{array}$ & $\cdots$ & $\begin{array}{r}-0.28 \\
(0.11)\end{array}$ \\
\hline Fraction female & $\begin{array}{c}0.29 \\
(0.16)\end{array}$ & $\ldots$ & $\begin{array}{c}0.67 \\
(1.07)\end{array}$ \\
\hline Average years of experience & $\begin{array}{l}20.50 \\
(2.10)\end{array}$ & $\cdots$ & $\begin{array}{c}-0.15 \\
(0.03)\end{array}$ \\
\hline Fraction married & $\begin{array}{c}0.71 \\
(0.06)\end{array}$ & $\cdots$ & $\begin{array}{c}0.83 \\
(1.23)\end{array}$ \\
\hline Fraction married females & $\begin{array}{c}0.19 \\
(0.10)\end{array}$ & $\ldots$ & $\begin{array}{c}-0.42 \\
(1.59)\end{array}$ \\
\hline Intercept & $\ldots$ & $\begin{array}{c}3.64 \\
(1.27)\end{array}$ & $\begin{array}{c}7.97 \\
(1.65)\end{array}$ \\
\hline $\bar{R}^{2}$ & $\ldots$ & 0.62 & 0.72 \\
\hline Number & 74 & 74 & 74 \\
\hline
\end{tabular}

Sources: The quit rate is from Employment and Earnings, vol. 29 (March 1982), table D-2, p. 110. The ln wage premium, average hourly wage, fraction married, and fraction married females were calculated from the Full Year 1984 CPS. Fraction union members average years of schooling, and average years of experience were calculated from the Full Year 1983 CPS. Fraction female is from Employment and Earnings, vol. 30 (January 1983), table 10, p. 150 .

a. Three-digit CIC industries.

b. The mean (standard deviation) of the dependent variable is $1.30(0.76)$. The numbers in parentheses in (1) and (2) are standard errors.

earnings have a correlation of -0.73 ; the quit rate and $\ln$ wage differential have an even stronger negative correlation of -0.79 .

The regressions in table 7 show that the negative correlation between industry wages and quit rates is accounted for by the industry wage premium and that the negative relationship of the industry wage premium and the quit rate remains when labor force characteristics and the extent

dummies; interactions of the female dummy with marriage, education, and education squared; and a constant. The sample used includes private sector, nonagricultural employees with complete information available on all the variables used in the regression. The sample size is 118,041 . 
of industry unionization are included as controls. The strong negative impact of the wage differential on the quit rate remains even when average establishment size and recent sales and employment growth variables are added to the regressor list. The estimates in the table indicate that a 0.20 increase in the ln wage premium is associated with a reduction in the quit rate of 8.9 to 10.2 per 100 employees per year, or 55 to 70 percent of the annual quit rate for the typical manufacturing establishment in 1981. These findings are consistent with those of Krueger and Summers and Akerlof, Rose, and Yellen that industry wage premiums are negatively related to quit rates in individual-level data when a variety of labor quality controls are included. Furthermore, Mincer and Higuchi find that industry wage differentials are strongly negatively related to quit rates even after controlling for differences in estimated industry-tenure slopes. ${ }^{41}$ The greatly reduced turnover associated with higher wages may partially offset the costs of high wages.

A further test of whether industry wage differentials reflect rents is whether high-wage-differential industries attract particularly long queues of job applicants. Using data on the number of job applicants per opening and starting wages for a large sample of employers, Holzer, Katz, and Krueger find that cities with higher unemployment rates have more job applicants per opening. ${ }^{42}$ This result shows that the number of job applicants per opening may be a reasonable measure of labor queues. The authors find a positive relationship between industry wage differentials and application differentials even after controlling for detailed job characteristics. High-wage industries attract more job applicants than low-wage industries. The mean number of applicants per opening in the five industries with the highest wage premiums was 14.0; the mean application rate for the five industries with the lowest wage premiums

41. Krueger and Summers, "Efficiency Wages," pp. 278-80; George A. Akerlof, Andrew V. Rose, and Janet L. Yellen, "Job Switching and Job Satisfaction in the U.S. Labor Market," Brookings Papers on Economic Activity, 2:1988, pp. 495-582; and Jacob Mincer and Yoshio Higuchi, "Wage Structures and Labor Turnover in the United States and Japan," Journal of the Japanese and International Economies, vol. 2 (1988), pp. 97-133.

42. Harry J. Holzer, Lawrence F. Katz, and Alan B. Krueger, "Job Queues and Wages," Harvard University, September 1988. The sample used, which is the only one available, oversamples small establishments and low-wage sectors of the economy. It is a far from ideal sample for examining the interindustry wage structure, since it has only very few observations from high-wage sectors and from large establishments where the industry wage differences are most substantial. 
was 8.5. ${ }^{43} \mathrm{~A} 10$ percent increase in the starting wage is estimated to have the same effect on the application rate as an increase in the unemployment rate of half a percentage point.

\section{Summary}

We have considered competitive explanations for industry wage differentials one at a time. Even if no one of them has great explanatory power for industry wage differentials, in totality they could account for much of the observed differences. For example, Kevin Murphy and Robert Topel (in work in progress) argue that if one is willing to assume that the low wages observed in education and welfare services reflect compensating differentials, then the remaining differentials may be more easily explained by unobserved ability. This strikes us as somewhat unlikely. The fact that evidence on quits and applications confirms our earlier statistical characterization of where workers earn rents suggests that our measures are picking up actual noncompetitive differences to a significant degree.

\section{Why Some Workers Earn Labor Market Rents}

The evidence presented in the preceding section shows that workers in some industries appear to receive rents. Their higher wages are difficult to account for on the basis of differences either in skill or in working conditions. Observed patterns of wage differentials seem to reflect some set of fundamental economic forces, since they are remarkably stable across time and space. Interestingly, they also appear to be very similar for different categories of workers. Secretaries and janitors, whose jobs would seem to be relatively standard across industries, display an interindustry wage structure like that of other workers.

To explain why firms in high-wage industries fail to cut wages in the absence of any legal compulsion, a natural economic approach is to identify the reasons that reducing wages would be unprofitable for a firm. That is the approach taken in the large and growing efficiency wage

43. If mining is removed from the high-wage group, the mean application rate increases to 17.5. The low application rate in mining suggests that part of its wage premium may reflect a compensating wage differential for hazardous working conditions. 
literature. ${ }^{44}$ This literature puts forth several reasons why firms may find that costs in the form of reduced productivity generated by wage reductions may exceed the direct benefits of such actions, even when there is an excess supply of labor.

Shapiro and Stiglitz, in the context of involuntary unemployment, and Bulow and Summers, in the context of wage differentials, emphasize the firms' need to deter their workers from shirking. ${ }^{45}$ Conferring rents on workers may be an efficient alternative to more extensive outlays for monitoring. If shirking is more costly with some production technologies than with others, different industries will naturally pay different wages. Other efficiency wage analyses deal with the firms' costs of hiring and firing, ease of recruiting, and selection of workers. ${ }^{46}$ In each case it is natural to suppose that the optimal wage for firms to pay will depend on their production technology.

Although these analyses surely help to explain industry wage differentials, they do not provide the whole story. At the theoretical level, the question arises of why firms do not extract rents from workers by selling jobs or engaging in some equivalent practice ${ }^{47}$ At the empirical level, another difficulty exists: though the need to motivate and retain workers in different occupations varies widely, there is, as already noted, a high degree of commonality across occupations in the interindustry wage structure.

44. See Joseph E. Stiglitz, "The Causes and Consequences of the Dependence of Quality on Price," Journal of Economic Literature, vol. 25 (March 1987), pp. 1-48, for a survey of the efficiency wage literature from a theoretical perspective; see Lawrence F. Katz, "Efficiency Wage Theories: A Partial Evaluation,"' NBER Macroeconomics Annual, 1986, vol. 1 (1986), pp. 235-76, for a survey from an empirical perspective.

45. Carl Shapiro and Joseph E. Stiglitz, "Equilibrium Unemployment as a Worker Discipline Device," American Economic Review, vol. 74 (June 1984), pp. 433-44; and Jeremy I. Bulow and Lawrence H. Summers, "A Theory of Dual Labor Markets with Application to Industrial Policy, Discrimination, and Keynesian Unemployment, ' Journal of Labor Economics, vol. 4 (July 1986), pt. 1, pp. 376-414.

46. See Joseph E. Stiglitz, "Equilibrium Wage Distributions," Economic Journal, vol. 95 (September 1985), pp. 595-618, for a model based on costs of hiring and firing; Kevin Lang, "Persistent Wage Dispersion and Involuntary Unemployment," Boston University and NBER, 1988, for a model based on recruiting considerations; and Andrew Weiss, "Job Queues and Layoffs in Markets with Flexible Wages," Journal of Political Economy, vol. 88 (June 1980), pp. 526-38, for a model based on adverse selection.

47. See Lorne Carmichael, "Can Unemployment Be Involuntary? Comment," American Economic Review, vol. 75 (December 1985), pp. 1213-14; and Murphy and Topel, "Efficiency Wages Reconsidered." 
One feature of efficiency wage equilibriums warrants comment. For firms paying the optimal wage, there is no cost to an incremental increase in wages. This suggests that if labor has any power at all, it will find it easy to extract (at least small) wage increases, since firms do not have strong incentives to resist those increases. Even in the absence of formal unions, labor may have some power. Akerlof draws on sociological studies of "gift exchange" theory to suggest that the performance of workers may depend on how fairly they think they are being treated..$^{48}$ Perceived fairness in turn depends on how profitable the firm is, and how essential the worker is to the production process. In a related vein, Raff and Summers argue that firms may share rents with workers in an effort to "buy the peace" and avoid the kind of collective, visible shirking that Mathewson and Mars find in many industrial settings. ${ }^{49}$

That finding suggests a possible role for rent sharing between firms and workers in determining the industry wage structure. Such sharing, if it goes on, might also help to explain the dearth of observed product market rents despite evidence that many firms are able to exert at least some degree of monopoly power. The importance of rent sharing in determining wages in unionized sectors has long been recognized. Rose presents evidence that the International Brotherhood of Teamsters, not the trucking companies, bore the primary brunt of the loss from trucking deregulation at the end of the 1970s. Freeman and Katz show that wage losses resulting from import competition were greater for union industries than for nonunion industries. ${ }^{50} \mathrm{Here}$, however, our focus is on what might be called "pure rent sharing," rent sharing in the absence of explicit collective bargaining.

Many industry wage differentials that are traditionally attributed to collective bargaining may in fact reflect more fundamental forces. Take

48. George A. Akerlof, "Gift Exchange and Efficiency-Wage Theory: Four Views,", American Economic Review, vol. 74 (May 1984, Papers and Proceedings, 1983), pp. 79-83.

49. Daniel M. G. Raff and Lawrence H. Summers, "Did Henry Ford Pay Efficiency Wages?' Journal of Labor Economics, vol. 5 (October 1987), pt. 2, pp. 557-86; Daniel M. G. Raff, "Wage Determination Theory and the Five-Dollar Day at Ford," Journal of Economic History, vol. 48 (June 1988), pp. 387-99; and Stanley B. Mathewson, Restriction of Output among Unorganized Workers (Southern Illinois University Press, 1969); and Gerald Mars, Cheats at Work: An Anthropology of Workplace Crime (London: Unwin, 1982).

50. Nancy L. Rose, "Labor Rent Sharing and Regulation: Evidence from the Trucking Industry," Journal of Political Economy, vol. 95 (December 1987), pp. 1146-78; and Freeman and Katz, "Industrial Wage and Employment Determination." 
Table 8. Industry Average Wages and the Extent of Unionization in U.S. Manufacturing, 1929, 1953-58

\begin{tabular}{|c|c|c|c|c|}
\hline \multirow[b]{2}{*}{ Industry } & \multicolumn{2}{|c|}{$\begin{array}{l}\text { Relative average } \\
\text { annual full-time } \\
\text { compensation } \\
\text { (manufacturing } \\
\text { average }=1.00 \text { ) }\end{array}$} & \multicolumn{2}{|c|}{$\begin{array}{l}\text { Extent of union } \\
\text { organization } \\
\text { (percent) }\end{array}$} \\
\hline & 1929 & 1958 & 1929 & 1953 \\
\hline Tobacco & 0.62 & 0.71 & 12 & 58 \\
\hline Textiles & 0.73 & 0.64 & 3 & 30 \\
\hline Lumber & 0.74 & 0.68 & 12 & 21 \\
\hline Leather & 0.83 & 0.64 & 12 & 39 \\
\hline Apparel & 0.85 & 0.61 & 29 & 53 \\
\hline Furniture & 0.88 & 0.74 & 3 & 29 \\
\hline Food & 0.95 & 0.86 & 4 & 45 \\
\hline Paper & 0.96 & 0.99 & 2 & 45 \\
\hline Miscellaneous manufacturing & 0.99 & 0.90 & 3 & 18 \\
\hline Stone, clay, glass & 0.99 & 0.95 & 9 & 45 \\
\hline Rubber & 1.00 & 1.01 & 0 & 54 \\
\hline Electrical machinery & 1.04 & 1.02 & 12 & 56 \\
\hline Nonferrous metals & 1.05 & 1.02 & 4 & 46 \\
\hline Chemicals & 1.06 & 1.15 & 0 & 39 \\
\hline Iron and steel & 1.10 & 1.11 & 5 & 58 \\
\hline Transportation equipment & 1.10 & 1.15 & 0 & 52 \\
\hline Automobiles & 1.14 & 1.25 & 0 & 80 \\
\hline Machinery, except electrical & 1.15 & 1.06 & 13 & 45 \\
\hline Petroleum & 1.21 & 1.54 & $\mathbf{0}$ & 67 \\
\hline Printing and publishing & 1.26 & 0.98 & 23 & 38 \\
\hline
\end{tabular}

Source: Derived from H. G. Lewis, Unionism and Relative Wages in the United States: An Empirical Inquiry (University of Chicago Press, 1963), pp. 289-90.

automobiles as an example. Raff and Summers, and Raff, demonstrate that wages in the auto industry rose with the introduction of assembly line technologies, since firms needed to improve discipline and cut down on absenteeism. ${ }^{51}$ Before their organization in the 1930s, automobile plants were already paying wages above the average for the whole of the manufacturing sector. The same was true for the steel industry.

Table 8 presents data originally compiled by H. G. Lewis on the extent of unionization and average annual total compensation wages in twenty manufacturing industries for the period 1929-58. The data show a weak negative correlation of -0.15 between unionization and wages in the manufacturing sector in 1929. The most heavily unionized industry,

51. Raff and Summers, "Did Henry Ford Pay Efficiency Wages?”; and Raff, "Wage Determination Theory.", 
apparel, actually paid lower wages than fifteen of the other nineteen industries in 1929 and than all of the other industries in 1958. But there is a clearly positive correlation between industry wage differentials in 1929 and the extent of unionization in 1958. And the correlation between wages in 1929 and subsequent changes in unionization is even a bit stronger.

Rather than being the cause of higher wages in all cases, unions often moved into relatively high-wage sectors after the passage of the National Labor Relations Act (Wagner Act) in 1935. This pattern may have two explanations. First, the presence of high initial wages was a sign that firms had substantial rents to share. Second, efficiency wage considerations may be more important in high-wage than low-wage industries, which implies that a given degree of bargaining power could push wages up further because the wage-productivity relationship was stronger. Either explanation is complemented by the consideration that because workers in high-wage industries are less likely to leave, they are more likely to be willing to invest in organizing activities. For our purposes, the exact reason why unions moved into high-wage industries after the passage of the Wagner Act is inessential. It suffices to note that the similarity of wage structures before and after unionization suggests that the factors which generate positive industry wage differentials in the highly unionized manufacturing in the postwar United States were present even in the absence of unionization. ${ }^{52}$

\section{Rent Sharing and the Characteristics of High-and Low-Wage Industries}

The characteristics of high-wage and low-wage industries in U.S. manufacturing are illustrated in the four parts of figure 3 . The tendency

52. There are of course cases where unions entered industries and did succeed in substantially increasing their relative wage. For example, because bituminous coal was very expensive to ship, unions had substantially more scope to raise firms' costs and extract rents from consumers than they did in industries like apparel that were subject to international competition. According to figures presented by Lewis, Unionism and Relative Wages, pp. 75-76, wages in this industry exceeded average manufacturing wages by an average of about 50 percent between 1900 and 1920, when about half the industry was unionized. This differential declined sharply to less than 25 percent in the late 1920s and early 1930s, as union coverage declined sharply to about 25 percent. After 1934, when unionism increased sharply to 90 percent, relative wages climbed steadily with the differential exceeding 70 percent in the late 1950 s. 
of capital-intensive industries (and those with a low labor share) to pay high wages is apparent. The relation between $R \& D$ spending and wages is positive but less clear-cut. One possible explanation for the correlation between wages and capital-to-labor ratios is complementarity between capital and skills. This explanation strikes us as implausible for janitors and secretaries, who, as we have seen, have an interindustry wage structure similar to that for other workers. A more likely explanation is that when the industry is capital intensive, labor has more leverage to extract rents and earn high wages. The relatively high wages received by airline pilots are a classic example of this type of rent extraction.

In an effort to examine the extent of rent sharing, we present in table 9 correlations between industry wage differentials in manufacturing and various industry characteristics. ${ }^{53}$ Several conclusions are apparent. First, there is a very strong correlation between total industry rents and labor market rents. Given the relative magnitudes of capital and labor rents, that should not be surprising. Second, there is a strong positive correlation between wage differentials and both the direct and market value measures of profitability. That is striking evidence for rent sharing, since any variations in labor's bargaining power could be expected to generate a negative correlation between labor and capital rents. Interestingly, the positive correlation between labor rents and profits per worker is far more significant than the correlation of either with the extent of unionism. Third, labor rents seem closely related to firms' capital-labor ratio, whereas capital rents decline with increases in the capital-labor ratio. Rents of both kinds appear to be strongly associated with R\&D intensity.

In table 10 we explore the simultaneous influence of different variables on wage differentials. The striking conclusion is that both the capitallabor ratio and the rate of profit enter significantly in explaining industry wages. As already suggested, this finding is consistent with the idea that labor can extract rents which depend on how much damage it could do by temporarily stopping the firm from producing. Production interruptions are more costly for capital-intensive firms and for those earning high profits than for other firms.

53. See Dickens and Katz, "Inter-Industry Wage Differences and Industry Characteristics," for a review of the extensive literature on industry wages and product market characteristics. 
Figure 3. Comparisons of Wage Premiums with Other Variables in Twenty Two-Digit Industries

Ln value added per worker

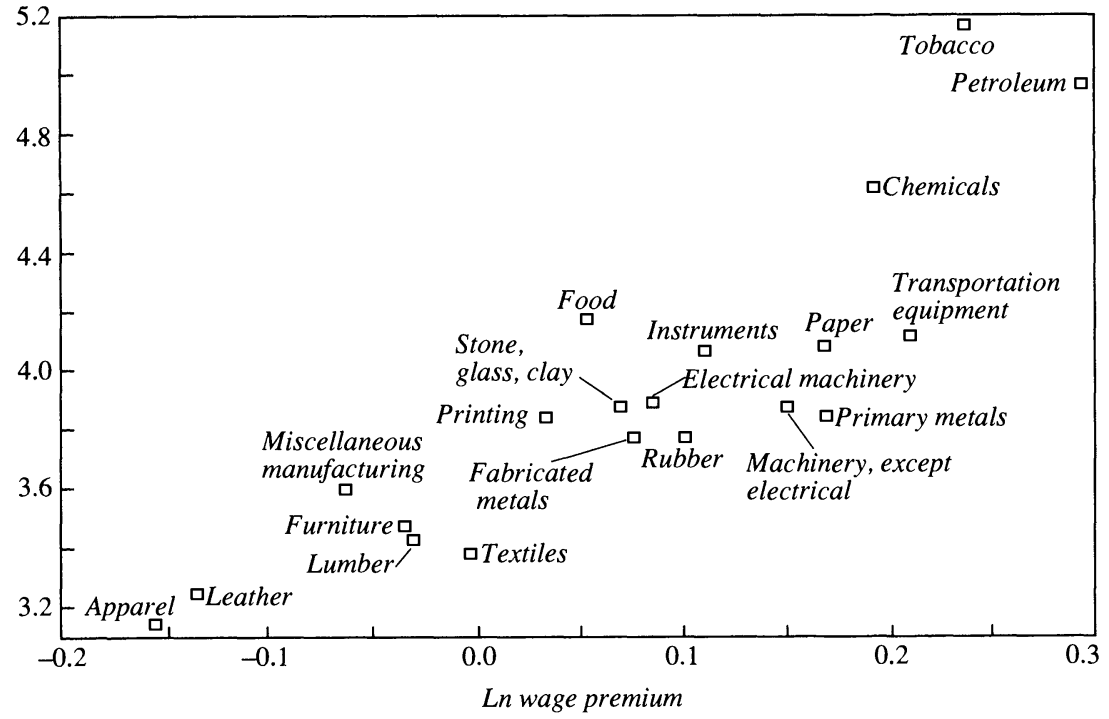

Ln capital-labor ratio

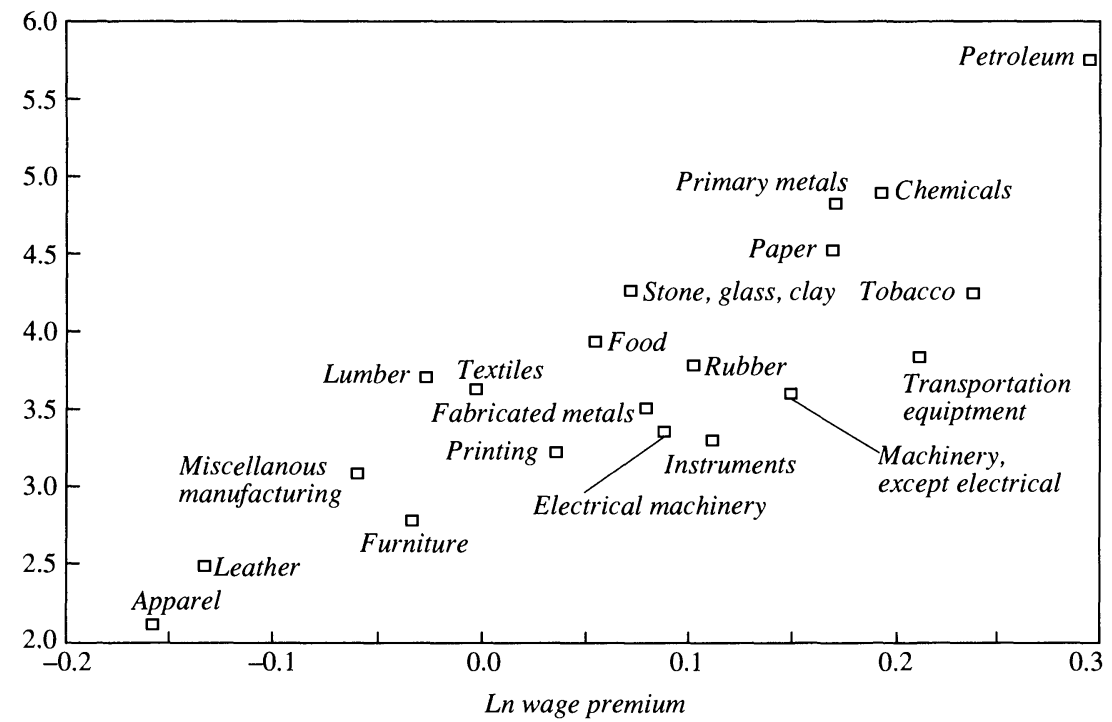

Sources: For wage premiums, authors' calculations using the Full Year 1984 CPS. For value-added per worker and capital-labor ratio, authors' calculations using data from the 1984 Annual Survey of Manufactures. For R\&D expenditures over sales, National Science Foundation, $R \& D$ in Industry (1981), tables A1, B3, B5, B11. For percent of employees that are union members, authors' calculations using the Full Year 1983 Current Population Survey. 


\section{Figure 3 (continued)}

$R \& D$ as percent of sales

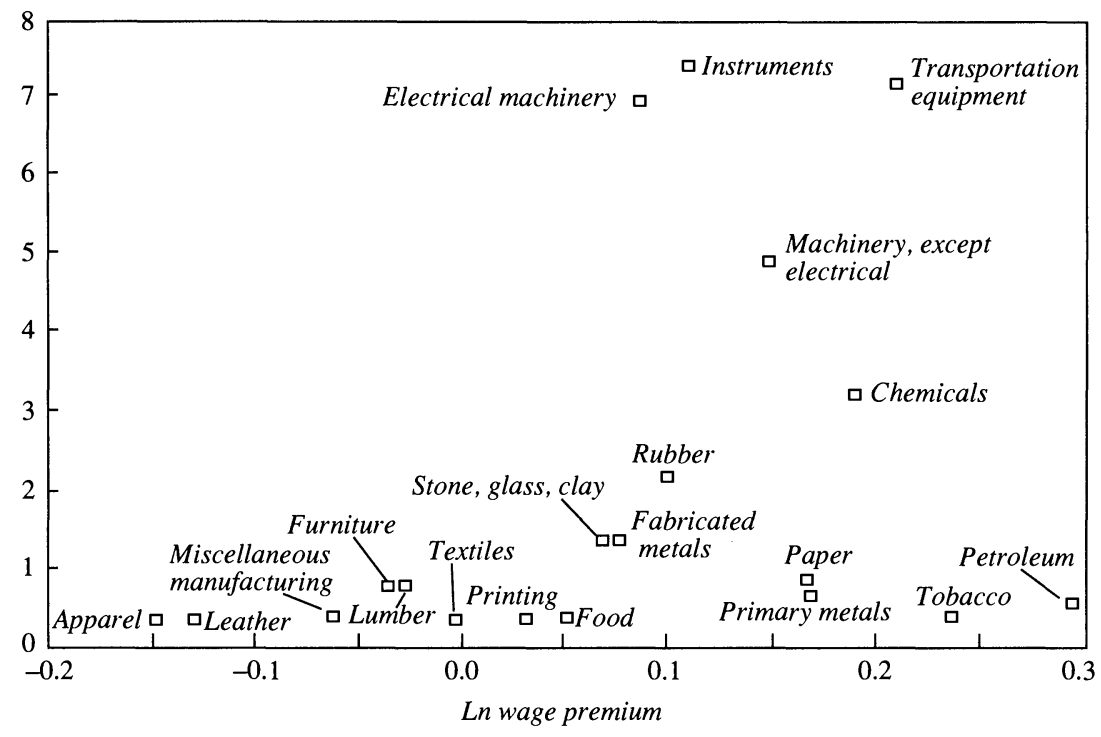

Percent union members

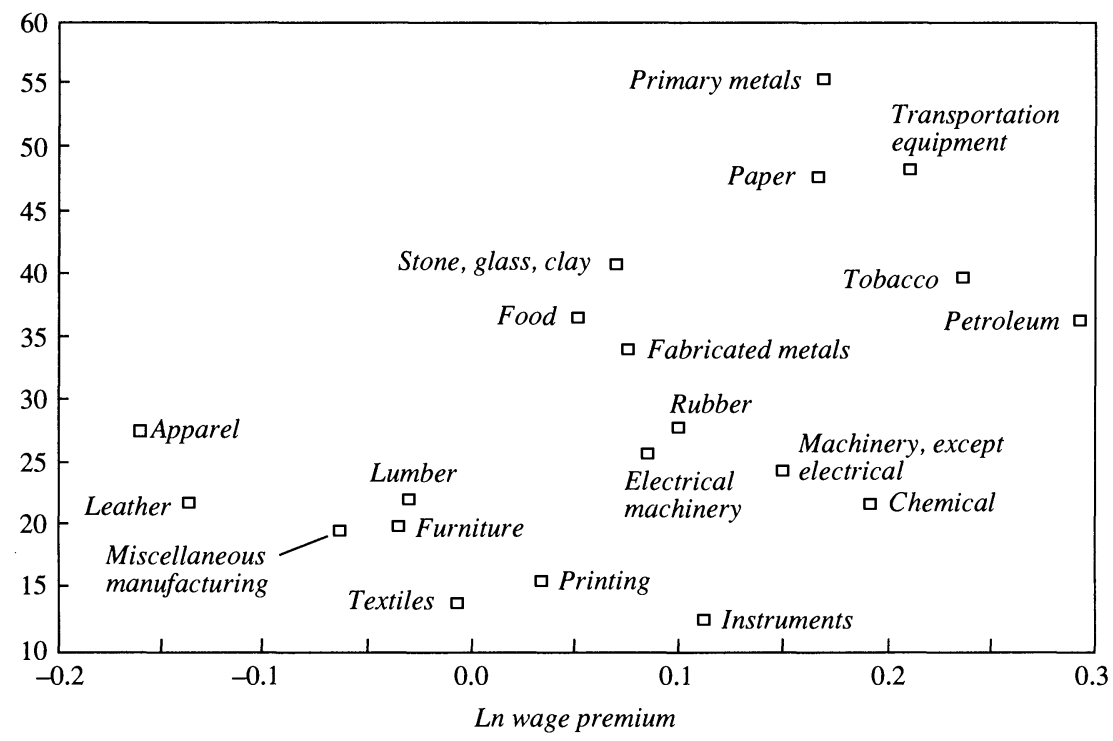




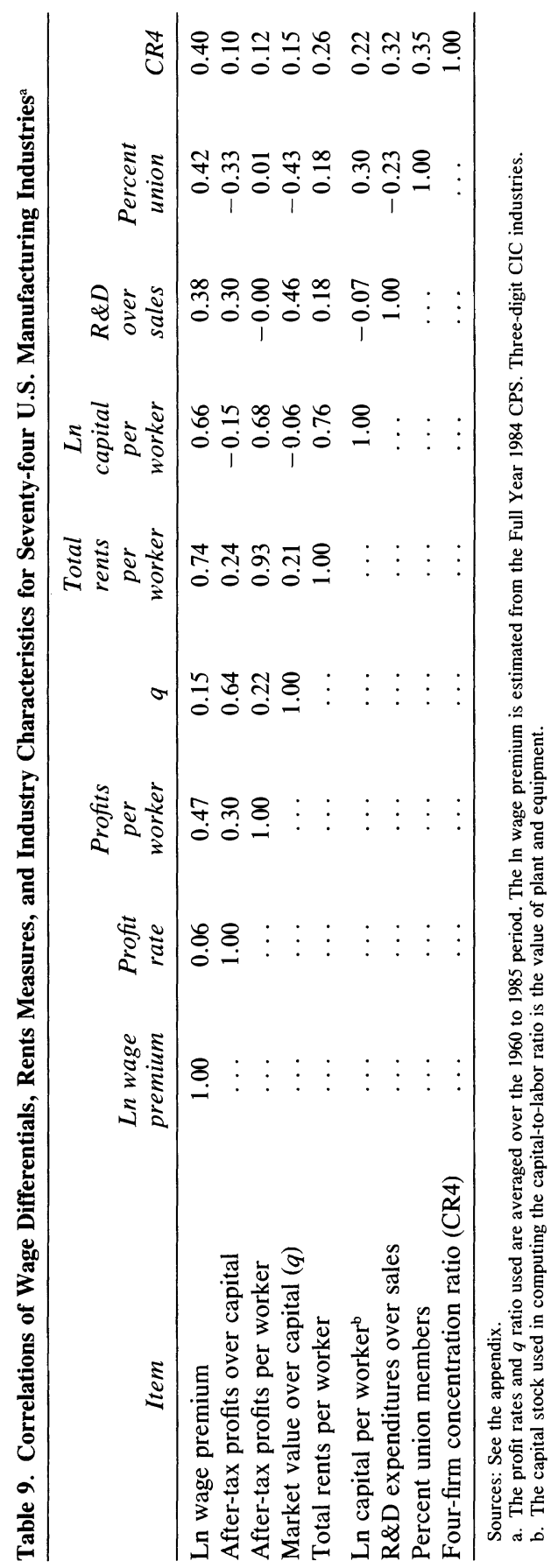


Table 10. Selected Regressions of Industry Wage Differentials and Industry Characteristics in U.S. Manufacturing ${ }^{\mathrm{a}}$

\begin{tabular}{lccc}
\hline \multirow{2}{*}{ Item } & \multicolumn{2}{c}{$\begin{array}{c}\text { Dependent variable: } \text { In industry } \\
\text { wage premium }\end{array}$} \\
\cline { 2 - 4 } & Mean & $(1)$ & $(2)$ \\
\hline After-tax profits per worker (thousands of & 5.43 & 0.0080 & $\ldots$ \\
$\quad$ 1984 dollars) & $(6.38)$ & $(0.0014)$ & \\
Fraction union members & 0.26 & 0.249 & 0.225 \\
& $(0.13)$ & $(0.068)$ & $(0.053)$ \\
Average number of employees per establishment & 62.50 & 0.0012 & 0.0005 \\
& $(39.4)$ & $(0.0002)$ & $(0.0002)$ \\
$q$ ratio & 1.30 & $\ldots$ & 0.024 \\
& $(0.74)$ & & $(0.010)$ \\
Capital per worker (millions of 1984 dollars) & 0.64 & $\ldots$ & 0.22 \\
& $(0.82)$ & & $(0.07)$ \\
Fraction female & 0.29 & $\ldots$ & -0.16 \\
& $(0.16)$ & & $(0.04)$ \\
Average years of experience & 20.40 & $\ldots$ & 0.012 \\
& $(1.90)$ & & $(0.004)$ \\
Average years of schooling & 12.00 & $\ldots$ & 0.070 \\
& $(0.83)$ & & $(0.010)$ \\
Ln employment growth, 1973-84 & -0.061 & $\ldots$ & 0.026 \\
Intercept & $(0.311)$ & & $(0.020)$ \\
$R^{2}$ & $\ldots$ & 0.48 & -1.01 \\
Number & & $(0.02)$ & $(0.15)$ \\
\hline
\end{tabular}

Sources: See the appendix.

a. Three-digit CIC industries.

b. The mean (standard deviation) of the dependent variable is $0.23(0.11)$. The numbers in parentheses in (1) and (2) are standard errors.

c. Market value divided by capital.

\section{The Relative Magnitude of Sectoral Variation in Labor and Capital Rents}

The evidence we have presented indicates that industry compensation differentials for similar workers are substantial and that these differentials significantly reflect labor rents. If even a moderate fraction of the skill-adjusted differentials are labor rents, then the variation in labor rents among sectors dwarfs the variation in capital rents. The relative magnitude of variation in labor and capital rents across seventy-four three-digit (CIC) manufacturing industries is illustrated in table 11. 
Table 11. Interindustry Variation in Labor and Capital Rents in Seventy-Four U.S. Manufacturing Industries ${ }^{\mathrm{a}}$

\begin{tabular}{lccc}
\hline \multicolumn{1}{c}{ Rent measure } & $\begin{array}{c}\text { Unweighted } \\
\text { standard } \\
\text { deviation }\end{array}$ & $\begin{array}{c}\text { Employment } \\
\text { weighted } \\
\text { standard } \\
\text { deviation }\end{array}$ & $\begin{array}{c}\text { Interquartile } \\
\text { range }\end{array}$ \\
\hline Ln wage premium & 0.11 & 0.10 & 0.14 \\
Labor rents per worker (1984 dollars) & 3,678 & 3,575 & 5,094 \\
Profits per worker (1984 dollars) & 6,301 & 4,230 & 3,102 \\
Labor rents over capital & 0.060 & 0.060 & 0.069 \\
Profits over capital & 0.022 & 0.019 & 0.024 \\
Labor rents over sales & 0.029 & 0.027 & 0.040 \\
Profits over sales & 0.016 & 0.014 & 0.021 \\
ratio & 0.73 & 0.58 & 0.45 \\
Present value of labor rents over capital & 1.27 & 1.26 & 1.46 \\
\hline
\end{tabular}

Source: Authors' calculations using data from various sources described in the appendix.

a. Three-digit CIC industries.

b. The profit rate and $q$ ratio used for creating the capital rent values are the average values for 1960-85. The 1984 industry ln wage premium $(P)$ is normalized so that industry 151 (apparel and accessories, except knit) has a value of zero.

Labor rents $=\pi \cdot$ total employee compensation, where $\pi=W D /(1+W D)$ and $W D=\exp (P)-1 . W D=$ wage differential.

Profits $=$ inflation adjusted after-tax net income plus interest.

$q=$ market value divided by capital.

Capital = inflation-adjusted net capital stock in 1984 .

Present value of labor rents $=21$ times labor rents. The average $q$ ratio for our sample over the $1960-85$ period is approximately 21 times the after-tax net rate of return on capital over this period.

We base our labor rent measures on industry wage differentials estimated from our Full Year 1984 CPS sample with a full set of control variables. The rent measure is normalized so that the wage differential for the industry with the lowest wage differential in manufacturing, apparel and accessories, except knit (CIC 151), is zero. (This normalization affects the level of but not the variation in industry labor rents.) The fraction of total industry employee compensation attributable to labor rents is assumed to be $\pi=W D /(1+W D)$, where $W D$ is the estimated percentage wage differential relative to apparel and accessories, except knit. Industry labor rents are then defined as $\pi$ times industry total employee compensation. We use inflation-adjusted after-tax operating profits as our flow measure of capital rents and the $q$ ratio as our measure of the present value of future capital rents.

Table 11 shows that even when all the variation in after-tax profits is attributed to capital rents rather than to variation in required rates of return to capital (possibly arising from differences in intangible capital), variation in labor rents is two to three times as large as variation in 
capital rents. ${ }^{54}$ These differences would be even larger if we used our total compensation differentials rather than wage differentials in computing labor rents or if we adjusted our capital rent measures for likely variation in the required rate of return. Thus even if only half of the estimated industry differentials reflect rents, sectoral variation in labor rents is more important than sectoral variation in rents to capital. The relative importance of labor rents suggests they ought to be at least as important a consideration as profit shifting in the design of trade and industrial policies.

\section{Wage Differentials and Trade Policies}

The basic argument linking labor market imperfections and trade policies has long been recognized by trade theorists. ${ }^{55}$ It has been echoed, though less clearly, in the American debate over industrial policies. If competitive forces do not equalize wages in different sectors and if firms operate on their labor demand curves, then the marginal product of labor in different sectors will not be equated, resulting in allocative inefficiencies. Policies that raise employment in high-wage sectors at the expense of employment in low-wage sectors will therefore increase allocative efficiency. This line of argument captures the thrust of industrial policy arguments suggesting that countries can raise their workers' standards of living by encouraging the growth of high-value-added industries.

We begin by demonstrating that the interaction of trade policies with wage differentials has welfare consequences likely to be more important than the profit-shifting effects that have been the focus of recent discussions of strategic trade policy. Then we examine arguments against subsidies to employment in high-wage sectors based on rent-seeking and equity considerations. We conclude that on economic grounds there is a moderately strong welfare argument for measures that promote production in high-wage-premium industries, though any policy judgment

54. The high standard deviation of profits per worker is driven by two extreme outliers, the Petroleum Refining Industry and Tobacco Industry. The interquartile range is probably a more reasonable metric of variability for this capital rents measure.

55. See, for example, Jagdish N. Bhagwati and T. N. Srinivasan, Lectures on International Trade (MIT Press, 1983); and Stephen P. Magee, International Trade and Distortions in Factor Markets (New York: Marcel Dekker, 1976). 
must depend on an assessment of how skillfully the government would manage its interventions.

\section{Wage Differentials in a Closed Economy}

For simplicity, consider a stylized economy with two sectors. ${ }^{56}$ Following the terminology of Doeringer and Piore in "Internal Labor Markets," we label these sectors secondary and primary. As will be discussed, the primary sector pays higher wages and offers workers more responsible jobs than the secondary sector. Secondary sector output, taken as the numeraire, is given by $Y^{n}=w_{0} L^{n}$. The secondary sector labor market is competitive, so that workers employed in the secondary sector receive a wage equal to their marginal product, $w_{0}$. Primary sector output is given by the constant-returns-to-scale production function $Y^{P}=F\left(K^{P}, L^{P}\right)$. The demand for primary sector output is a decreasing function of its price, $p=p\left(Y^{P}\right), p^{\prime}<0$. We assume that the wage differential, $d$, in the primary sector is a nondecreasing function of employment, $d=d\left(L^{P}\right), d^{\prime} \geq 0 .{ }^{57}$ It may depend positively on the level of employment because workers' ability to extract rents is increased when the demand for labor increases, or because the cost of leaving a high-wage job is reduced when there are more high-wage jobs in the economy.

Assume initially that the economy is closed and that the capital stock is fixed. Firms in the primary and secondary sector product markets are assumed to act competitively. Then the first-order condition,

$$
p\left(Y^{P}\right) F_{L}\left(K^{P}, L^{P}\right)=w_{0}(1+d),
$$

determines the level of primary sector employment, which is inefficiently low. As figure 4 illustrates, a subsidy to employment in the primary sector at a rate just sufficient to offset the wage differential $1 /(1+d)$ would permit the economy to attain the first-best allocation of labor. The optimal subsidy will be set at $d\left(L^{P^{\prime}}\right)$, where $L^{P^{\prime}}$ is the level of primary

56. At the cost of some complexity, the special assumption that capital is not used in producing secondary sector output could be relaxed. It does capture the stylized fact noted in the previous section that high-wage sectors tend to be capital intensive.

57. See Bulow and Summers, "A Theory of Dual Labor Markets," for an explicit derivation of a $d\left(L^{P}\right)$ schedule from an efficiency wage model. 
Figure 4. Subsidies and Economic Efficiency

Wages
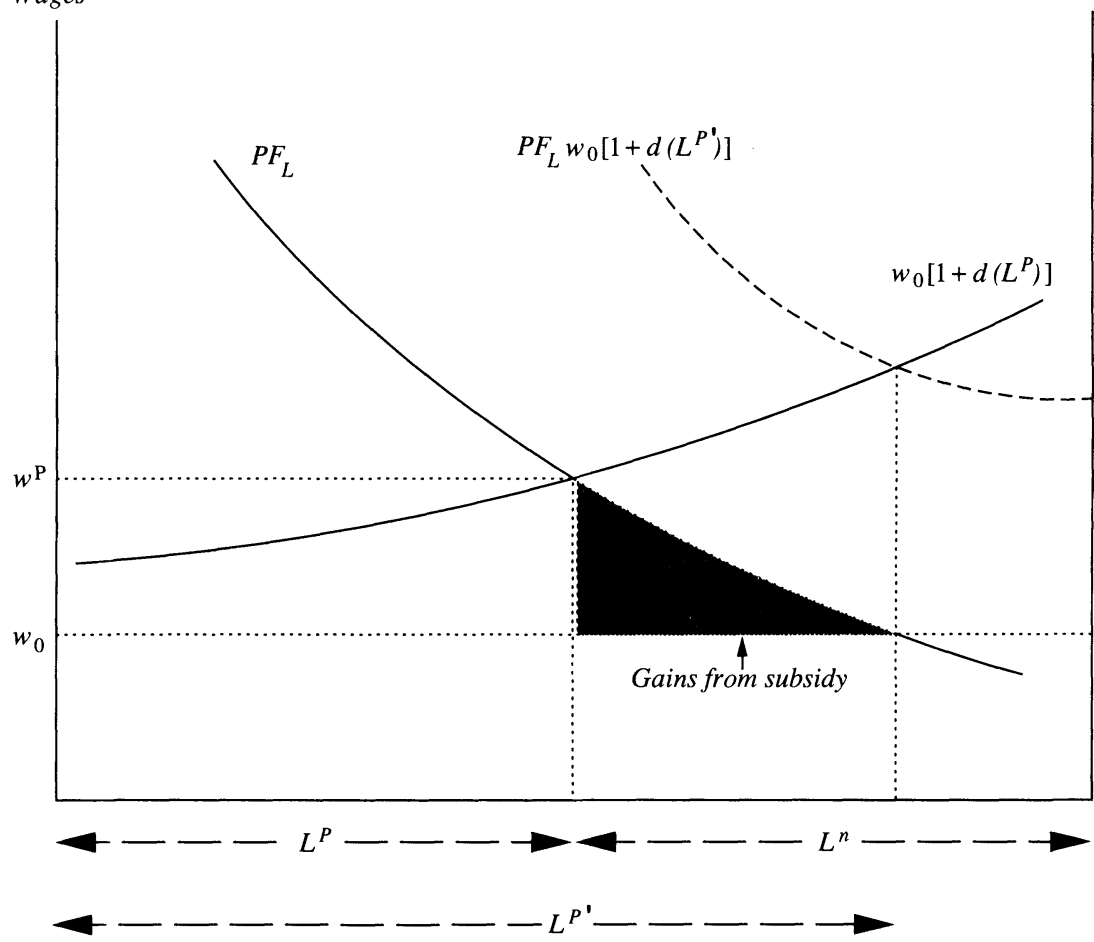

$w^{P}=$ marginal product of workers in the primary sector

$w_{0}=$ marginal product of workers in the secondary sector

$L^{P}=$ level of primary sector employment

$L^{n}=$ level of secondary sector employment

$P F_{L}=$ demand curve for labor in the primary sector $=p\left(Y^{P}\right) F_{L}\left(K^{P}, L^{P}\right)$

$d\left(L^{P}\right)=$ required wage differential in primary sector as a function of level of primary sector employment

sector employment, where $p\left(Y^{P}\right) F\left(K^{P}, L^{P}\right)=w_{0}$. Note that such a subsidy increases efficiency, even though it may lead to a widening of interindustry wage differentials. We return later to the question whether it represents a Pareto improvement.

How substantial are the potential gains from public policies directed at offsetting the effects of interindustry wage differentials? One way to answer this question is to compare the efficiency costs of interindustry wage differentials with other distortions that have received more atten- 
tion from economists. Earlier we showed that, after correcting for measured ability differences, the standard deviation of differentials of nonunion industry compensation was about 18 percent. About 15 percent of American workers in the private sector are covered by trade union agreements, and it is generally estimated that their compensation is about 20 percent above those of other workers. If that were the only source of wage inequality, the standard deviation of wages would be approximately 7 percent. ${ }^{58}$ Thus the allocative inefficiency due to industry wage effects exceeds that due to union wage differentials, even if only half the observed differentials reflect noncompetitive wage premiums.

A different standard of comparison is the distortionary consequence of taxation. Assuming that labor's share in output is about three-quarters, a 20 percent differential in labor costs between two sectors will affect the product mix in the same way as a 60 percent capital income tax or a 15 percent sales tax. The 60 percent figure is more than what is at stake in the much discussed distortion between corporate capital and owneroccupied housing. Much smaller differentials in effective tax rates played a prominent role in the recent U.S. tax reform debate. Discussions of sales taxes invariably treat differences of only a few percentage points in the rates on included and excluded items as a serious problem.

In highlighting the potential gains from subsidies to high-wage industries, we have maintained the assumptions that the capital stock is fixed, that firms take wages as given and operate on their labor demand curves, and that product markets are perfectly competitive. Our preceding discussion of the sources of labor market rents raises questions about the validity of each of these assumptions. If wages are not set competitively, but instead arise in part from implicit or explicit bargaining between workers and firms, one can expect that workers' success in bargaining over wages will affect firms' decisions on capital investment. In settings where firms bargain with groups of workers, it has been understood since the work of Wassily Leontief that points on the labor demand curve are inefficient in that some wage-employment combina-

58. Union numbers are from Richard B. Freeman, "Contraction and Expansion: The Divergence of Private Sector and Public Sector Unionism in the United States,' Journal of Economic Perspectives, vol. 2 (Spring 1988), pp. 63-88. For a review of evidence on union wage differentials, see Richard B. Freeman and James L. Medoff, What Do Unions Do? (Basic Books, 1984). 
tions will be preferred by both employers and workers. ${ }^{59}$ And probably some labor rents come at the expense of monopoly rents that firms would otherwise enjoy.

Let us first consider the question of variable capital intensity. If firms operate on their labor demand curves so that the wage and marginal product of labor are equated, the same subsidy policies that are optimal with fixed capital are optimal with variable capital. With a subsidy that reduces the cost of hiring labor to its social opportunity cost, firms have just the right incentives for investing in new plant and equipment.

Things become more complex when we allow for the possibility of efficient bargains between workers and firms that generate employment levels off the labor demand curve.${ }^{60}$ Suppose initially that a firm bargains over wages and employment with a union which can costlessly redistribute income among its members. Then the firm will use labor up to the efficient (competitive) point where its marginal product is equal to labor's opportunity cost. But the union will use its bargaining power to extract premium wages from the firm. As a result, the firm will hire the efficient number of workers, but find itself hiring more than it would have hired if unconstrained at the observed wage. In this instance, there will be an observed wage premium but no labor market case for any subsidy to employment in the high-wage sector. If redistributions between workers in the union are impossible and they have diminishing marginal utility of income, unions may even push employment beyond the competitive level as a way of optimally sharing rents among workers. If so, it might actually be appropriate to tax high-wage employment.

For several reasons we doubt that off-the-demand-curve bargains between workers and firms could significantly qualify our conclusion that subsidies to high-wage employment are likely to enhance economic efficiency. First, it is by no means clear that bargains between workers and firms cover both wages and employment even in the unionized sector. Typical union contracts specify wage scales in considerable detail and are specific about grievance procedures and many aspects of working conditions. But they do not tend to have provisions restricting firms'

59. Wassily Leontief, "The Pure Theory of the Guaranteed Annual Wage Contract," Journal of Political Economy, vol. 54 (February 1946), pp. 76-79.

60. For a clear statement of the formal models underlying this discussion, see Andrew J. Oswald, "The Economic Theory of Trade Unions: An Introductory Survey," Scandinavian Journal of Economics, vol. 87, no. 2 (1985), pp. 160-93. 
ability to determine how many workers to hire. Although implicit bargains over employment are possible, they seem unlikely in light of general claims by firms, often with the acquiescence of their unions, that they have "the right to manage." Recent empirical evidence suggests that firms' employment levels are sensitive to their own wages in a manner consistent with employment outcomes in union contracts that are determined on a conventional downward-sloping demand curve. The evidence is much more ambiguous about the dependence of employment on the measures of workers' outside opportunities. ${ }^{61}$

Most of the wage differentials that are the subject of this paper antedate the presence of unions and are replicated in areas in which union power is minimal. In nonunion settings it is hard to see what would cause firms to ever deviate from their labor demand curve, given the observed level of wages. In union settings the union might retaliate for excessive layoffs; in nonunion settings it is more difficult to believe that workers would retaliate on behalf of laid-off workers.

Second, standard treatments of the efficient bargains model omit an important consideration. Suppose unions care only about the welfare and employment of their current members. As long as a union has fewer members than would be employed if its industry operated competitively, efficient bargains will employ all union members at a wage determined by the relative bargaining powers of the firm and union. Under these circumstances excessive industry employment is impossible, so that a subsidy will be either neutral or desirable in its effects. As long as the common presumption that unions reduce employment is maintained, a subsidy to high-wage employment must be either neutral or desirable in terms of efficiency.

An interesting relationship also exists between efficient bargains and firms' investment decisions. If the unions are able to extract higher wages when firms become more capital intensive, firms will systematically underinvest in capital. Even if union bargains are efficient after the fact, in that the marginal product of labor is equated to its opportunity cost, firms will underinvest if extra capital intensity forces them to pay higher wages. ${ }^{62}$ In effect, the ability of workers in certain sectors to

61. David Card, "Unexpected Inflation, Real Wages, and Employment Determination in Union Contracts," 'Working Paper 2768 (NBER, November 1988).

62. See Paul A. Grout, "Investment and Wages in the Absence of Binding Contracts: A Nash Bargaining Approach," Econometrica, vol. 52 (March 1984), pp. 449-60, for a formal analysis of this case. 
extract rents from sunk investments acts as a tax on capital investment in those sectors. That creates an argument for subsidizing investment in high-wage industries where bargaining power is abnormally strong, even though no subsidy to employment is appropriate.

On balance, it appears that if high-wage employment can be increased at the expense of low-wage employment without collateral costs, economic efficiency will presumably be enhanced. Later we consider some possible collateral costs. But first it is instructive to consider the possibility of interactions between labor market rents and the rents associated with imperfectly competitive firms, since as a rule high-wage firms systematically tend to have more product market power than other firms. The question then arises whether the product market effects of subsidies to the variable input of industries with relatively more monopoly power are likely to enhance welfare.

Unfortunately, it is easily demonstrated that no firm judgments about the product market effects of subsidy policies are possible. In the simplest case of a pure monopoly, a subsidy is desirable on efficiency grounds because it brings product prices down toward marginal costs. However, this conclusion can easily be reversed for monopolistic competition. Then subsidies are likely to encourage rent dissipation through excessive entry if products are homogeneous. When the entry of new firms into an industry generates increases in consumer surplus through increased product differentiation, the possibility that subsidies will increase welfare reemerges. ${ }^{63}$ As recent work using calibrated partial equilibrium models shows, any robust conclusions about the product market effects of various trade and industrial policies are almost impossible to reach. ${ }^{64}$

In effect, the dual observations that product market considerations lead to much less robust policy conclusions than labor market rent considerations, and that rent differentials in labor markets dwarf those in product markets, make it seem appropriate to focus on the labor market in considering sectoral policies. For simplicity we now return to

63. N. Gregory Mankiw and Michael D. Whinston, "Free Entry and Social Inefficiency,"' Rand Journal of Economics, vol. 17 (Spring 1986), pp. 48-58.

64. Kala Krishna, Kathleen Hogan, and Phillip Swagel, "The Non-Optimality of Optimal Trade Policies: The U.S. Automobile Industry Revisited, 1979-1985, " Harvard University, January 1989, find that small changes in the specification of the nature of product market competition greatly alter the policy recommendations and welfare results arising from a calibration exercise for the U.S. automobile industry. They also find that the implications of labor rents for policy are more robust to changes in product market assumptions. 
our original assumptions that firms set employment and that product markets are competitive.

\section{Wage Differentials in a Small Open Economy}

For a small open economy, illustrated in the bottom part of figure 5, the relative price of primary sector output is determined on international markets and is assumed to be unaffected by the domestic production mix. The demand function $p\left(Y^{P}\right)$ becomes perfectly elastic. This does not change equation 1 or the desirability of employment subsidies for the primary sector. Opening up the economy does, however, strengthen the case for large subsidies. In a closed economy (top part of the figure), subsidies to the primary sector encounter diminishing returns as its output declines in value with increased production. That does not happen when the price of output is set on world markets and is insensitive to the level of domestic production. ${ }^{65}$

A further point needs to be made. As the figure shows, the marginal welfare gained per dollar of subsidy will be greater the greater the world price of primary sector output relative to the secondary sector wage. As the world price of the primary sector output expands, and so domestic production expands, the wage differential increases, raising the social gain to inducing further expansion of the primary sector. This observation resonates somewhat with discussions of industrial policy which claim that governments should support "sunrise" export industries rather than "sunset" import-competing industries.

Any discussion of activist trade policies typically stresses a potential defect: that they invite retaliation, which will offset any initial benefits. This argument does not apply when policy options are limited to subsidies directed at capturing labor market rents. Countries would indeed prefer that their subsidies to primary sector output not meet retaliation. However, subsidies that are retaliated against by similar subsidies are nonetheless likely to raise the welfare of both countries in the model

65. We focus on the small open economy to highlight the implications of wage differentials for trade policy. For open economies large enough to affect the prices at which they buy and sell, there are traditional optimal tariff considerations as well. These suggest the desirability of taxing rather than subsidizing exports when expanding exports can lead to at least a moderate terms-of-trade deterioration. In that case, our analysis of employment subsidies is correct if it is assumed that optimal tariffs (taxes) based on these traditional considerations are already in place. 
Figure 5. Subsidies in Closed and Open Economies

Wages

Autarky

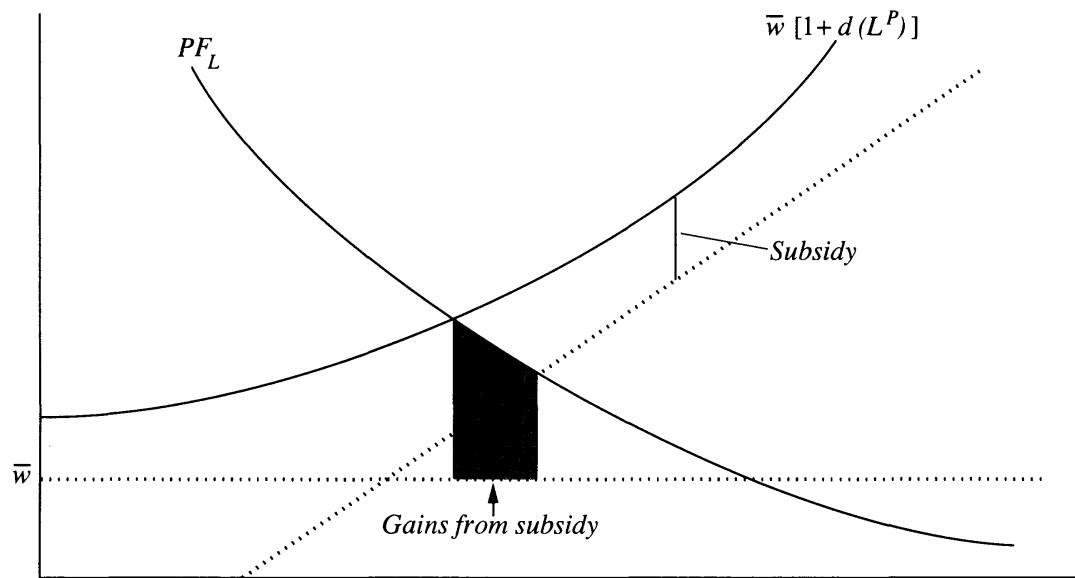

Employment

Wages

Free Trade

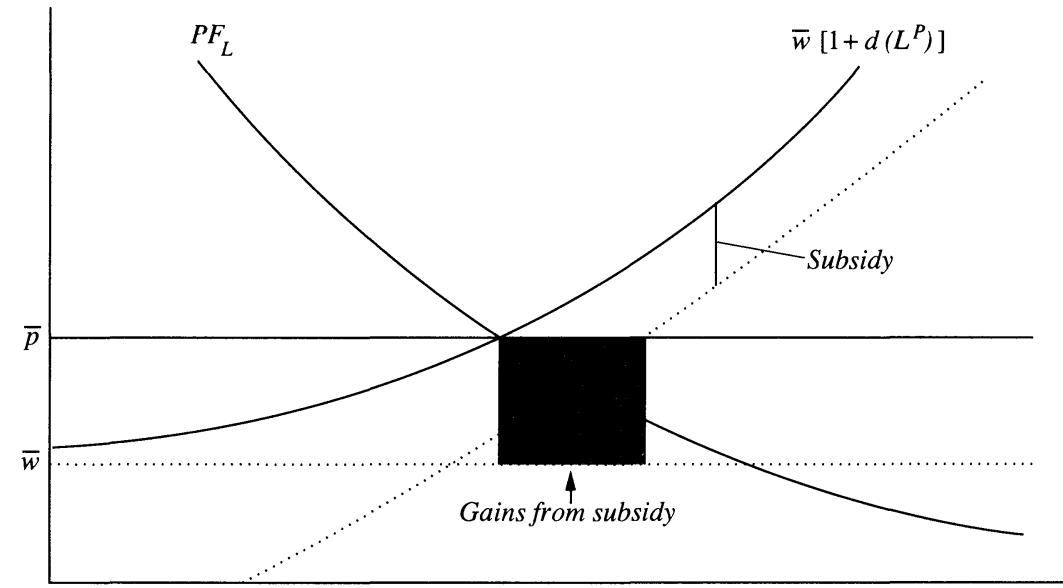

Employment

$\bar{w}=$ secondary sector wage

$\bar{p}=$ world price 
illustrated in figures 4 and 5. For they will drive the world economy to a situation like the subsidized first-best optimum depicted in figure 4. Note further that subsidies beyond the point where the marginal product of labor in the primary and secondary sectors are equated are inefficient in both open and closed economies.

\section{Gauging the Importance of Labor Rents}

Under most plausible estimates, the wage differential effects stressed here are of greater importance for trade policy than the product market monopoly rent-shifting effects discussed in recent work on strategic trade policy. The point may be illustrated more strongly by considering two recent studies of strategic trade policies: Baldwin and Krugman's study of European subsides to Airbus Industrie for the development of the A300 jet; and Dixit's study of trade in automobiles. ${ }^{66}$

Baldwin and Krugman construct a simple simulation model incorporating both learning curve effects and strategic interactions in aircraft industry. Their data indicate that the subsidy program substantially affected the allocation of airplane production between the United States and Europe. It also reduced prices in the industry considerably. Baldwin and Krugman's analysis infers that the subsidy program cost the European airline industry $\$ 1.47$ billion in profits and increased the consumer surplus of European customers by $\$ 1.43$ billion, leading to only a negligible change in economic welfare. But their analysis takes no account of the rents gained by labor as it moved from lower-wage industries into the high-wage airplane industry. A policy analysis should not treat the rent component of the wage bill as a social cost of production but as a component of the social surplus generated by the industry. ${ }^{67}$

To estimate the labor rent effects of the Airbus program, we assumed

66. Richard Baldwin and Paul Krugman, "Industrial Policy and International Competition in Wide-Bodied Jet Aircraft," NBER, June 1987; Richard Baldwin and Paul Krugman, "Modelling International Competition in High Technology Industries: Lessons from Aircrafts and Semiconductors," NBER Conference on Empirical Studies of Strategic Trade Policy, September 1987; and Avinash Dixit, " Optimal Trade and Industrial Policy for the U.S. Automobile Industry,"' in Robert C. Feenstra, ed., Empirical Methods for International Trade (MIT Press, 1988), pp. 141-65.

67. This point is well known from the development literature on project evaluation; for example, Raaj Kumar Sah and Joseph E. Stiglitz, "The Social Cost of Labor and Project Evaluation: A General Approach,' Journal of Public Economics, vol. 28 (November 1985), pp. 135-63. 
that compensation in the entire product chain of airplanes was 25 percent higher than the economy average and alternatively that it was 25 percent higher in only the final stage of production, airline assembly. Combining these figures with Baldwin and Krugman's estimates of the diversion of sales toward the Airbus consortium and information on labor's share in airplane production permits a rough estimate of the labor-rent-shifting effect of the subsidies to Airbus.

The results in table 12 show that once labor rent considerations are recognized, the overall assessment of the Airbus program for European welfare turns from marginally negative to strongly positive. Even in the less favorable case, the subsidies generate a welfare gain equal to about half their cost. Considering the high level of unemployment in Europe, the estimated gain would be far greater if we assumed that some of those hired by Airbus would otherwise have been unemployed.

Dixit's recent study of the automobile industry suggests a similar conclusion. The author finds that allowing for labor rents in the American automobile industry dramatically alters the results of his analysis based on imperfect competition in the product market. Policies promoting domestic production that appear undesirable when labor market imperfections are ignored yield moderate gains once the existence of these imperfections is acknowledged.

There needs to be more careful empirical analysis of other specific incidents before firm judgments about the potential importance of labor rent shifting can be made. Dixit, and Baldwin and Krugman, chose their examples because of potentially important product market imperfections. It would be valuable to examine industries, such as steel, that are noted for large labor market imperfections.

\section{Some Possible Objections}

Our analysis so far has assumed away rent-seeking behavior. At least two kinds of rent seeking need to be considered. First, it is possible that wage differentials generate wait unemployment of the sort envisioned by Harris and Todaro. ${ }^{68}$ In the extreme case in which the primary sector

68. John R. Harris and Michael P. Todaro, "Migration, Unemployment and Development: A Two-Sector Analysis," American Economic Review, vol. 60 (1970), pp. 126-42. 
Table 12. Labor Market Rents and the Effects of the Airbus A300 Program on European Welfare ${ }^{a}$

\begin{tabular}{|c|c|c|c|}
\hline \multirow[b]{2}{*}{ Item } & \multicolumn{3}{|c|}{ Scenario } \\
\hline & $\begin{array}{l}\text { No labor rents } \\
\text { (1) }\end{array}$ & $\begin{array}{l}20 \text { percent } \\
\text { labor rents at } \\
\text { final stage of } \\
\text { production }^{\mathrm{b}} \\
\text { (2) }\end{array}$ & $\begin{array}{c}20 \text { percent } \\
\text { labor rents at } \\
\text { all stages of } \\
\text { production }{ }^{\mathrm{c}} \\
\text { (3) }\end{array}$ \\
\hline $\begin{array}{l}\text { Change in present discounted value } \\
\text { of consumer surplus }\end{array}$ & 1.43 & 1.43 & 1.43 \\
\hline $\begin{array}{l}\text { Change in present discounted value } \\
\text { of profits }\end{array}$ & -1.47 & -1.47 & -1.47 \\
\hline $\begin{array}{l}\text { Change in present discounted value } \\
\text { of labor rents } \\
\text { Net change in welfare }\end{array}$ & $\begin{array}{r}0.00 \\
-0.04\end{array}$ & $\begin{array}{l}0.90 \\
0.86\end{array}$ & $\begin{array}{l}1.84 \\
1.80\end{array}$ \\
\hline $\begin{array}{l}\text { Sources: Adapted from Richard Baldwin an } \\
\text { Technology Industries: Lessons From Aircraft } \\
\text { Strategic Trade Policy, September 1987, table } \\
\text { Information on employee compensation, value } \\
3721 \text { ) are from Bureau of Census, } 1985 \text { Annual St } \\
\text { (Department of Commerce, 1987). } \\
\text { a. All figures are in billions of dollars. The } \\
\text { production of } 398 \text { units over a twenty-year produ } \\
\text { b. The change in labor rents is computed as } \\
\text { calculated from the Baldwin-Krugman simulation } \\
\text { of shipments in the U.S. aircraft industry in } 1985 \\
\text { c. The change in labor rents is computed in } \\
\text { employee compensation in value added in the U. }\end{array}$ & $\begin{array}{l}\text { laul Krugman, "Mod } \\
\text { Semiconductors," } \\
\text { Changes in labor ren } \\
\text { hipments, and value } \\
\text { y of Manufactures, } S \\
\text { mputations assume a } \\
\text { cycle. } \\
\text { change in the present } \\
15.41 \text { billion) times th } \\
291 \text { ) times the share } \\
\text { lanner analogous to t } \\
\text { aircraft industry in } 19\end{array}$ & $\begin{array}{l}\text { lling International } \\
\text { BER conference on } \\
\text { are based on the } \\
\text { added for the U.S. } \\
\text { atistics for Industry } \\
5 \text { percent discount } \\
\text { discounted value of } \\
\text { ratio of employee } \\
\text { f rents in employee } \\
\text { at described in note } \\
5(0.596) \text { replacing }\end{array}$ & $\begin{array}{l}\text { ompetition in High- } \\
\text { Empirical Studies of } \\
\text { uthors' calculations. } \\
\text { rcraft industry (SIC } \\
\text { roups and Industries } \\
\text { ate and cumulative } \\
\text { hipments for Airbus } \\
\text { mpensation to value } \\
\text { ompensation (0.20). } \\
\text { b, with the share of } \\
\text { e share of employee }\end{array}$ \\
\hline
\end{tabular}

hires randomly each period from a pool of waiting applicants, $w^{P}(1-$ $u)=w_{0}$, where $u$ is the unemployment rate in the primary sector. Here there is no gain to increasing primary sector employment, since for each job created in the primary sector, $u /(1-u)$, workers move from the lowwage sector into unemployment. ${ }^{69} \mathrm{~A}$ more plausible formulation of wait unemployment would recognize that incumbent employees usually retain the rights to their jobs each period, so that only new openings and those jobs where the incumbent worker has quit or been terminated are available to be allocated to the unemployed. Under this scenario, if workers have positive discount rates and enter the primary sector queue to the point where the utility of being in the queue equals the utility of being employed in the low-wage sector, extra employment in the primary

69. Since each new job created in the primary sector removes $1 /(1-u)$ workers from secondary employment and since $w_{0} /(1-u)=w^{P}$, the social opportunity cost of labor for an additional job in the primary sector equals the marginal product of labor in the primary sector. 
sector will generate less induced unemployment than in the extreme case. Thus a small subsidy to the primary sector will still be desirable. Furthermore, if workers are able to queue for high-wage jobs from lowwage jobs, rent seeking through wait unemployment may not be an important problem. ${ }^{70}$

The second type of rent-seeking behavior involves efforts to create wage differentials. Union-organizing drives are an obvious example. If larger wage differentials lead to larger employment subsidies, such rentseeking activity will be encouraged. In that case, subsidies to high-wage industries, while increasing efficiency after the fact, may create large ex ante inefficiencies if more resources are devoted to trying to push up wages. We doubt this point is of great practical importance. Unionorganizing budgets and expenditures incurred by employer resistance are trivial compared with the rents earned by union workers. Taking 20 percent of the work force to be unionized and a 20 percent union compensation effect implies that 4 percent of wages, or about $\$ 75$ billion a year, consists of rents. Union-organizing budgets in the United States certainly total far less than $\$ 1$ billion. Furthermore, as the evidence surveyed earlier suggests, most wage differentials do not arise from union-organizing activity.

A different line of argument against policies directed at subsidizing the primary sector stresses their antiegalitarian consequences. The essence of such policies is, after all, subsidizing workers who are receiving relatively high wages. The argument is more subtle, however, than it at first appears. Subsidies to the primary sector enlarge it, thereby raising the probability that secondary sector workers can move into the primary sector. Bulow and Summers demonstrate that, compared with the free market, small subsidies to the primary sector make some people better off without making others worse off (Pareto improvements), in the special case where all workers are homogeneous, movements between sectors can be characterized by a Markov process (a constant probability of moving between sectors), and efficiency wage considerations lead to constant lifetime utility differences between workers in the two sectors. More generally, efficiency-enhancing subsidies will not

70. See Amartya Sen, Employment, Technology and Development (Oxford University Press, 1975), pp. 51-59, for a more detailed discussion of why the labor rents generated from an expansion of primary sector employment are unlikely to be fully dissipated through wait unemployment. 
produce Pareto improvements, particularly if there are some secondary sector workers who have no chance of getting primary sector jobs because of their lack of skills. ${ }^{71}$ One may also argue that optimal subsidies should be given to improve the allocation of output, and then income redistribution measures used to offset any perverse distributional consequences. $^{72}$

\section{Wage Differentials and American Trade Policies ${ }^{73}$}

The belief that international competition is profoundly changing the economic landscape and leading to the deindustrialization of America is often expressed in debates over American industrial policy. The crude argument that the United States is losing its manufacturing base to international competitors is often put forward to justify policies directed at limiting imports or spurring exports. In George Meany's picturesque comment, "You cannot have a healthy economy based on everyone doing everyone else's laundry."

The assertion that the United States might lose its ability to compete in all industries rests on confusion. Since foreigners are unlikely to be willing to accumulate claims on American assets indefinitely, the United States must ultimately run a trade surplus. The interesting question for structural trade policy, therefore, is whether a trade balance with a high level of both exports and imports or one with a low level of both exports and imports is preferable.

To shed light on this issue, tables 13, 14, and 15 present information on the characteristics of American manufacturing industries, distinguishing between import and export industries. We focus only on manufac-

71. Bulow and Summers, "Theory of Dual Labor Markets.",

72. The issue is complex because policies that tax high-wage workers for the benefit of low-wage workers will, at least in some efficiency wage models, have perverse effects on the composition of output by reducing the relative utility of primary sector workers. Thus income redistribution policies may undo the allocative effects of subsidies to sectors that pay wage premiums. Income redistribution measures that do not undo the allocative effects of such subsidies are likely to be possible insofar as the wage differentials in the targeted sectors represent pure rent-sharing considerations.

73. An analysis of labor rents and trade policies paralleling in many respects the one given here is presented in William T. Dickens and Kevin Lang, "Why It Matters What We Trade: A Case For Active Policy," in Laura D'Andrea Tyson, William T. Dickens, and John Zysman, eds., The Dynamics of Trade and Employment (Ballinger Press, 1988), pp. 87-112. Our analysis differs from theirs in contrasting the relative importance of labor market and product market imperfections and in focusing on the manufacturing sector. 
Table 13. High Import Penetration and Export Supply Ratio in U.S. Manufacturing Industries, 1984

\begin{tabular}{|c|c|c|c|c|c|}
\hline \multicolumn{6}{|c|}{ Industries employing top 10 percent of workers by import penetration ratio ${ }^{\mathrm{b}}$} \\
\hline $\begin{array}{l}\text { Census } \\
\text { industry } \\
\text { code }\end{array}$ & Industry & $M /(M+S)^{\mathfrak{c}}$ & $\begin{array}{c}\text { Total rents } \\
\text { over } \\
\text { capital }\end{array}$ & $\begin{array}{l}\text { Ln wage } \\
\text { premium }\end{array}$ & $\begin{array}{l}\text { Employment } \\
\text { (thousands) }\end{array}$ \\
\hline 221 & Footwear, except rubber & 0.597 & 0.125 & -0.209 & 107.3 \\
\hline 381 & Watches, clocks, and watchcases & 0.534 & 0.158 & -0.147 & 13.4 \\
\hline 222 & Leather products & 0.433 & 0.104 & -0.217 & 45.4 \\
\hline 391 & $\begin{array}{l}\text { Jewelry and miscellaneous manu- } \\
\text { facturing }\end{array}$ & 0.410 & 0.159 & -0.149 & 268.7 \\
\hline 321 & Office and accounting machines & 0.368 & 0.268 & 0.068 & 54.7 \\
\hline 261 & Pottery & 0.357 & 0.167 & -0.170 & 37.0 \\
\hline 390 & $\begin{array}{l}\text { Toys, amusements, and sporting } \\
\text { goods }\end{array}$ & 0.309 & 0.161 & -0.098 & 86.6 \\
\hline 151 & Apparel and accessories & 0.302 & 0.111 & -0.227 & 974.1 \\
\hline 351 & Motor vehicles & 0.215 & 0.256 & 0.155 & 752.7 \\
\hline
\end{tabular}

Industries employing top 10 percent of workers by export supply ratio ${ }^{\mathrm{d}}$

\begin{tabular}{|c|c|c|c|c|c|}
\hline $\begin{array}{l}\text { Census } \\
\text { industry } \\
\text { code }\end{array}$ & Industry & $X / S^{\mathrm{e}}$ & $\begin{array}{c}\text { Total rents } \\
\text { over } \\
\text { capital }\end{array}$ & $\begin{array}{l}\text { Ln wage } \\
\text { premium }\end{array}$ & $\begin{array}{l}\text { Employment } \\
\text { (thousands) }\end{array}$ \\
\hline 352 & Aircraft and aircraft parts & 0.369 & 0.372 & 0.141 & 516.8 \\
\hline 312 & Construction machinery & 0.285 & 0.143 & 0.111 & 237.7 \\
\hline 322 & Electronic computing equipment & 0.264 & 0.206 & 0.124 & 373.7 \\
\hline 361 & Railroad equipment & 0.224 & 0.166 & 0.159 & 29.5 \\
\hline 371 & Scientific instruments & 0.222 & 0.291 & 0.008 & 267.9 \\
\hline 310 & Engines and turbines & 0.214 & 0.299 & 0.191 & 105.7 \\
\hline 191 & Agricultural chemicals & 0.211 & 0.114 & 0.022 & 45.3 \\
\hline 220 & Leather, tanning, and finishing & 0.191 & n.a. & -0.128 & 16.7 \\
\hline 192 & Industrial chemicals & 0.180 & 0.160 & 0.160 & 317.8 \\
\hline
\end{tabular}

Sources: Trade flow and employment data are from the NBER Trade-Immigration-Labor Market Dataset. The total rents over capital and ln wage premium variables are based on the author's calculations using the NBER R\&D Master File and the Full Year 1984 CPS. See the appendix for details.

n.a. Not available.

a. Total rents over capital are the sum of the net pretax rate of return on capital and labor rents divided by the adjusted capital stock. The $\ln$ wage premium is normalized so that the typical manufacturing worker has a ln wage premium equal to zero.

b. The employment weights used in calculations for the top 10 percent of import workers are total employment for the top eight industries and 198,200 for motor vehicles.

c. $M /(M+S)$ is the import penetration ratio, where $M=$ imports and $S=$ shipments of domestic producers.

d. The employment weights used in calculations for the top 10 percent of export workers are total employment for the top eight industries and 192,100 for industrial chemicals.

e. $X / S$ is the export supply ratio, where $X=$ exports and $S=$ shipments of domestic producers.

turing because of data limitations regarding other sectors, and because manufacturing accounts for the lion's share (about two-thirds) of American trade. ${ }^{74}$ The data refer to three-digit census industries. The number of import or export workers in each industry is estimated as the product of the industry's total number of employees and the fraction of total industry shipments represented by imports or exports.

74. See Dickens and Lang, "Why It Matters What We Trade," for consideration of the relation between U.S. trade and wages outside of the manufacturing sector. 
Table 14. Characteristics of Import and Export Sectors, U.S. Manufacturing Industries, 1984

\begin{tabular}{|c|c|c|c|c|c|}
\hline \multirow[b]{2}{*}{ Characteristic } & \multicolumn{5}{|c|}{ Industries employing a } \\
\hline & $\begin{array}{c}\text { Typical } \\
\text { manufacturing } \\
\text { workers } \\
\text { (I) }\end{array}$ & $\begin{array}{l}\text { Top 10 } \\
\text { percent } \\
\text { import } \\
\text { workers } \\
\text { (2) }\end{array}$ & $\begin{array}{l}\text { Top 10 } \\
\text { percent } \\
\text { export } \\
\text { workers } \\
\text { (3) }\end{array}$ & $\begin{array}{l}\text { Typical } \\
\text { import } \\
\text { workers } \\
\text { (4) }\end{array}$ & $\begin{array}{c}\text { Typical } \\
\text { export } \\
\text { workers } \\
(5)\end{array}$ \\
\hline $\begin{array}{l}\text { Average hourly wage for production } \\
\text { workers in } 1983 \text { (dollars) }\end{array}$ & $\begin{array}{c}8.91 \\
(1.92)\end{array}$ & 6.48 & 10.33 & 8.28 & 9.55 \\
\hline Ln wage premium for all workers & $\begin{array}{c}0.00 \\
(0.11)\end{array}$ & -0.154 & 0.113 & -0.037 & 0.050 \\
\hline $\begin{array}{l}\text { Ln wage premium for nonunion } \\
\text { workers }\end{array}$ & $\begin{array}{c}0.00 \\
(0.10)\end{array}$ & -0.120 & 0.126 & -0.017 & 0.056 \\
\hline $\begin{array}{l}\text { Ln wage premium for union } \\
\text { workers }\end{array}$ & $\begin{array}{c}0.00 \\
(0.12)\end{array}$ & -0.186 & 0.067 & -0.054 & 0.031 \\
\hline Percent female & $\begin{array}{c}33.2 \\
(18.2)\end{array}$ & 63.8 & 24.6 & 41.7 & 32.1 \\
\hline Percent black & $\begin{array}{l}10.3 \\
(3.6)\end{array}$ & 12.7 & 7.2 & 10.7 & 8.8 \\
\hline Percent unionized & $\begin{array}{c}28.6 \\
(14.1)\end{array}$ & 27.6 & 28.2 & 28.4 & 28.5 \\
\hline $\begin{array}{l}R \& D \text { expenditures as percent of } \\
\text { sales }\end{array}$ & $\begin{array}{c}2.9 \\
(3.5)\end{array}$ & 1.3 & 8.6 & 3.0 & 5.4 \\
\hline Percent production workers & $\begin{array}{c}70.4 \\
(12.6)\end{array}$ & 81.2 & 54.9 & 73.7 & 65.3 \\
\hline Average years of schooling & $\begin{array}{l}12.1 \\
(0.9)\end{array}$ & 11.2 & 13.3 & 11.9 & 12.6 \\
\hline $\begin{array}{l}\text { Value added per worker (thousands } \\
\text { of } 1984 \text { dollars) }\end{array}$ & $\begin{array}{c}55.0 \\
(23.4)\end{array}$ & 33.8 & 68.8 & 48.3 & 60.6 \\
\hline $\begin{array}{l}\text { Capital-to-labor ratio (thousands of } \\
1984 \text { dollars) }\end{array}$ & $\begin{array}{c}53.3 \\
(60.7)\end{array}$ & 22.5 & 65.7 & 48.2 & 54.8 \\
\hline$M /(M+S)$ (percent) & $\begin{array}{l}11.7 \\
(9.8)\end{array}$ & 33.5 & 10.1 & 22.4 & 12.2 \\
\hline$X / S$ (percent) & $\begin{array}{c}8.4 \\
(9.2)\end{array}$ & 4.4 & 27.6 & 8.3 & 16.5 \\
\hline
\end{tabular}

Sources: Dickens-Katz 1983 Industry Data Set; NBER Trade-Immigration-Labor Market Industry Data Set; NBER R\&D Master File. See the appendix for details.

a. Columns 1, 2, and 3 are three-digit CIC industry averages weighted by industry employment. Import and export rankings are based on 1984 trade data. Columns 2 and 3 present average characteristics of the top 10 percent of workers by industry import penetration $(M /[M+S])$ and export intensity $(X / S)$, respectively. Column 4 weights industry average characteristics by industry employment times $M / S$. Column 5 weights industry average characteristics by industry employment times $X / S . M=$ imports, $X=$ exports, $S=$ shipments of domestic producers. The numbers in parentheses are standard deviations.

Table 13 lists the manufacturing industries with the highest import and export shares. Most of the export industries rely heavily on high technology, aircraft and scientific instruments being prominent examples. The import industries are more mixed, ranging from footwear to office machines to motor vehicles. Particularly for export industries, it is striking that durable and capital goods play an important role in 
Table 15. Total, Capital, and Labor Rents and Trade Flows in U.S. Manufacturing Industries, 1984

\begin{tabular}{|c|c|c|c|c|c|}
\hline \multirow[b]{2}{*}{ Item } & \multicolumn{5}{|c|}{ Industries employing ${ }^{\mathrm{a}}$} \\
\hline & $\begin{array}{c}\text { Typical } \\
\text { manufacturing } \\
\text { workers } \\
\text { (1) }\end{array}$ & $\begin{array}{c}\text { Top } 10 \\
\text { percent } \\
\text { import } \\
\text { workers } \\
\quad \text { (2) }\end{array}$ & $\begin{array}{c}\text { Top } 10 \\
\text { percent } \\
\text { export } \\
\text { workers } \\
\text { (3) }\end{array}$ & $\begin{array}{c}\text { Typical } \\
\text { import } \\
\text { workers } \\
\text { (4) }\end{array}$ & $\begin{array}{c}\text { Typical } \\
\text { export } \\
\text { workers } \\
\text { (5) }\end{array}$ \\
\hline \multicolumn{6}{|l|}{ Total Rents } \\
\hline $\begin{array}{l}\text { Total rents per worker (thousands } \\
\text { of } 1984 \text { dollars) }\end{array}$ & $\begin{array}{l}13.360 \\
(9.05)\end{array}$ & 6.68 & 19.55 & 11.57 & 15.77 \\
\hline Total rents over capital stock & $\begin{array}{c}0.201 \\
(0.076)\end{array}$ & 0.144 & 0.270 & 0.190 & 0.240 \\
\hline Total rents over sales & $\begin{array}{c}0.113 \\
(0.030)\end{array}$ & 0.067 & 0.147 & 0.102 & 0.130 \\
\hline \multicolumn{6}{|l|}{ Capital Rents } \\
\hline $\begin{array}{l}\text { Before-tax profits per worker } \\
\text { (thousands of } 1984 \text { dollars) }\end{array}$ & $\begin{array}{c}7.59 \\
(6.63)\end{array}$ & 4.68 & 9.33 & 6.60 & 8.20 \\
\hline $\begin{array}{l}\text { Before-tax profits over capital } \\
\text { stock }\end{array}$ & $\begin{array}{c}0.110 \\
(0.038)\end{array}$ & 0.118 & 0.113 & 0.114 & 0.117 \\
\hline Before-tax profits over sales & $\begin{array}{c}0.063 \\
(0.025)\end{array}$ & 0.054 & 0.066 & 0.060 & 0.065 \\
\hline \multicolumn{6}{|l|}{ Labor Rents } \\
\hline $\begin{array}{l}\text { Labor rents per worker (thousands } \\
\text { of } 1984 \text { dollars) }\end{array}$ & $\begin{array}{c}5.77 \\
(3.58)\end{array}$ & 2.00 & 10.22 & 4.97 & 7.57 \\
\hline Labor rents over capital & $\begin{array}{c}0.091 \\
(0.060)\end{array}$ & 0.025 & 0.157 & 0.076 & 0.123 \\
\hline Labor rents over sales & $\begin{array}{c}0.050 \\
(0.027)\end{array}$ & 0.013 & 0.082 & 0.042 & 0.065 \\
\hline
\end{tabular}

Sources: Profit rates are averages for 1960 to 1985 calculated from the NBER R\&D Master File. Labor rents were calculated using wage differentials estimated from the Full Year 1984 CPS. See the appendix for details.

a. See table 14 .

merchandise trade. The table also illustrates that almost all the large export-intensive sectors pay positive wage premiums, whereas all the major import-intensive sectors except motor vehicles are low-wage sectors within manufacturing. A similar pattern is observed for total rents over capital.

Intraindustry trade is very important even at the three-digit level; the correlation between import and export shares was 0.06 in 1984 . To highlight the differences between import and export workers, the first three columns of table 14 compare the average characteristics of the most import-intensive and most export-intensive industries with those of the entire manufacturing sector.

A clear pattern emerges from the table. Relative to the entire manufacturing sector, export industries look much more like the primary sector firms, whereas import industries look much more like secondary 
sector firms. After being adjusted for skill differences, wages in exportintensive industries are 11 percent above average, whereas wages in import-intensive industries are 15 percent below average. Roughly similar differentials are observed for both union and nonunion workers. The widely cited examples of automobiles and steel, where very high wage industries face substantial import penetration and are almost completely unable to export, appear to be atypical. As a rule exportintensive industries are the ones that have substantial wage premiums.

Reflecting patterns of American comparative advantage, exportintensive industries in the United States also employ more skilled workers and do more research and development than import-intensive industries. The former industries devote 8.6 percent of sales to $R \& D$, compared with 1.3 percent for the latter. The average worker in exportintensive industry has thirteen years of schooling; the average worker in import-intensive industry has eleven. Import-intensive industries also disproportionately employ women, blacks, and immigrants, whereas export industries employ those workers to less than the average extent.

The comparisons of the characteristics of the industries employing typical export and import workers (columns 4 and 5 of table 14) suggest all the same qualitative conclusions as the more extreme comparisons of export- and import-intensive industries. Industry differences are attenuated, for in many cases export- and import-intensive industries coincide because of the importance of intraindustry trade. Nonetheless, the skill-adjusted wage differential between the typical export and import worker is about 9 percent.

Table 15 contrasts various measures of total rents in export-intensive and import-intensive industries. As the previous discussion would lead one to expect, variations in the total rent measures are dominated by variations in labor rents, so that export industries continue to appear more rent-intensive than import industries. There do not seem to be large differences between export- and import-intensive industries in our measures of capital market rents. But though the qualitative conclusions about import- and export-intensive industries are unaffected, clearly the quantitative conclusions about high- and low-wage industries are sensitive to what denominator is used in measuring rents. That is because of very substantial interindustry differences in the capital-to-labor ratios.

These results imply that, for the United States, policies which succeed in promoting trade and increasing the volume of both exports and imports 
will tend to raise welfare by moving workers from lower- to higher-wage industries. The gains are potentially significant. For example, the estimates here suggest that eliminating a manufacturing trade deficit of $\$ 150$ billion by raising exports rather than by reducing imports would increase labor rents by at least $\$ 13$ billion. If export-intensive industries were expanded relative to import-intensive industries, the gains could be up to three times as great.

\section{International Comparisons}

We have already documented that the wage structure is very similar in all countries. It follows that there is no way in which all countries can disproportionately export goods produced with high-wage labor. A reasonable conjecture is that one concomitant of increased economic development is increased comparative advantage in the production of primary sector goods. To examine this possibility, table 16 presents evidence on the American wage premium of import-and export-intensive industries for a number of countries, along with information on the American wage premium associated with the industries employing typical export and import workers.

The data provide initial support for our conjecture about patterns of economic development. South Korea imports goods produced by highwage industries and exports goods produced by low-wage industries, not simply because of their abundance of low-skilled labor. The wage premiums used in these comparisons are estimated by controlling for measured labor quality, and as the evidence cited earlier suggests, they do not primarily reflect unobserved aspects of skill. Most of the developed countries appear to export relatively high-wage premium goods while importing relatively low-wage goods. It is interesting that the difference in wage premiums between high and low net export industries is particularly pronounced in Germany and Japan.

\section{Trends in American Trade}

Discussions of American competitiveness have differed on whether the changing trade patterns of recent years are simply the consequence of aberrant exchange rate movements brought about macroeconomic policies and speculative forces, or are instead the result of long-term 
Table 16. U.S. Natural Log Wage Premiums of Import and Export Workers in Manufacturing in Nine Countries, 1983

\begin{tabular}{|c|c|c|c|c|c|}
\hline \multirow[b]{2}{*}{ Country } & \multicolumn{5}{|c|}{ Worker } \\
\hline & $\begin{array}{c}\text { Typical } \\
\text { manufacturing }\end{array}$ & $\begin{array}{l}\text { Typical } \\
\text { import }^{\mathrm{b}}\end{array}$ & $\begin{array}{l}\text { Typical } \\
\text { export }\end{array}$ & $\begin{array}{c}\text { In top } 10 \\
\text { percent } \\
\text { net } \\
\text { export } \\
\text { industries }\end{array}$ & $\begin{array}{c}\text { In } \\
\text { bottom } \\
10 \\
\text { percent } \\
\text { net } \\
\text { export } \\
\text { industries }\end{array}$ \\
\hline Australia & 0.006 & 0.019 & 0.063 & 0.132 & 0.034 \\
\hline Chile & -0.024 & -0.000 & 0.017 & 0.013 & 0.055 \\
\hline France & 0.016 & 0.037 & 0.053 & 0.110 & 0.020 \\
\hline Germany & 0.045 & 0.021 & 0.051 & 0.145 & -0.106 \\
\hline Japan & 0.002 & -0.012 & 0.030 & 0.134 & -0.113 \\
\hline South Korea & -0.039 & 0.020 & -0.089 & -0.216 & 0.077 \\
\hline Sweden & 0.030 & 0.001 & 0.035 & 0.053 & -0.045 \\
\hline United Kingdom & 0.014 & 0.013 & 0.027 & 0.082 & -0.128 \\
\hline United States & 0.000 & -0.004 & 0.033 & 0.051 & -0.170 \\
\hline
\end{tabular}

Sources: This table uses data from eighteen ISIC (international standard industrial classification) manufacturing industries: $321,322,323,324,331,332,341,342,351,355,361,362,371,372,381,382,383,384$. Trade flow data on an ISIC basis were provided by Robert Stern of the University of Michigan. The U.S. industry ln wage premium variable aggregates up industry wage differentials were estimated from the Full Year 1983 CPS using employment weights from three-digit CIC industries to ISIC industries. Employment data are from United Nations, Industrial Statistics Yearbook, 1984, vol. 1: General Industrial Statistics.

a. Three-digit ISIC U.S. industry In wage premiums weighted by each country's industry employment.

b. Three-digit ISIC U.S. industry ln wage premiums weighted by each country's industry employment times $M / S$ (imports over shipments of domestic producers).

c. Three-digit ISIC U.S. industry ln wage premiums weighted by each country's industry employment times $X / S$ (exports over shipments of domestic producers).

structural deterioration. A central issue in the deindustrialization debate is whether the United States has suffered particularly severe competitive losses in "good industries," variously defined as those that emphasize technology or have high value added per worker. The analysis in the preceding section suggests that examining the relative performance of high- and low-wage industries probably provides the best way of getting at this issue.

Assuming fixed ratios of employment to shipments, table 17 indicates how changing trade patterns have affected employment in high- and lowwage industries. Between 1960 and 1980 the number of jobs displaced by imports was approximately equal to the number of jobs created by exports. Particularly during the 1970 s increased imports led to a reallocation of labor out of the lowest-wage jobs in the manufacturing sector, and increased U.S. exports led to a rise in employment in high-wage sectors of the economy. During the 1980s the fraction of workers employed in producing tradable goods declined as the trade deficit increased. Between 1980 and 1984, the last year for which we have data, 
Table 17. Direct Impact of International Trade on Employment Wage Class, U.S. Manufacturing, 1960-84

\begin{tabular}{|c|c|c|c|}
\hline \multirow[b]{2}{*}{ Wage premium class ${ }^{\mathrm{a}}$} & \multicolumn{3}{|c|}{ Change in employment (in thousands) from ${ }^{b}$} \\
\hline & Imports & Exports & Net exports \\
\hline \multicolumn{4}{|l|}{ Overall manufacturing } \\
\hline $1960-84$ & $-2,621.3$ & $1,107.1$ & $-1,514.2$ \\
\hline $1980-84$ & $-1,248.0$ & -168.4 & $-1,416.5$ \\
\hline $1970-80$ & -941.5 & 946.7 & 5.2 \\
\hline $1960-70$ & -431.7 & 328.9 & -102.9 \\
\hline \multicolumn{4}{|l|}{ Lowest quartile } \\
\hline $1960-84$ & $-1,021.7$ & 71.8 & -950.0 \\
\hline $1980-84$ & -576.2 & -60.7 & -636.9 \\
\hline $1970-80$ & -307.6 & 113.3 & -194.3 \\
\hline $1960-70$ & -138.0 & 19.2 & -118.8 \\
\hline \multicolumn{4}{|l|}{ Second quartile } \\
\hline $1960-84$ & -457.2 & 323.0 & -134.1 \\
\hline $1980-84$ & -217.7 & 10.1 & -207.6 \\
\hline $1970-80$ & -177.5 & 242.8 & 65.3 \\
\hline $1960-70$ & -61.9 & 70.1 & 8.2 \\
\hline \multicolumn{4}{|l|}{ Third quartile } \\
\hline $1960-84$ & -547.8 & 271.5 & -276.2 \\
\hline $1980-84$ & -220.5 & -70.1 & -290.6 \\
\hline $1970-80$ & -229.9 & 251.5 & 21.6 \\
\hline $1960-70$ & 97.4 & 90.1 & -7.2 \\
\hline \multicolumn{4}{|l|}{ Highest quartile } \\
\hline $1960-84$ & -594.7 & 440.8 & -153.9 \\
\hline $1980-84$ & -233.7 & -47.6 & -281.3 \\
\hline $1970-80$ & -226.6 & 339.1 & 112.5 \\
\hline $1960-70$ & -134.4 & 149.4 & 15.0 \\
\hline
\end{tabular}

Source: Authors' calculations using data from the NBER Trade-Immigration-Labor Market Dataset.

a. Industries were ranked by their In industry wage premium estimated from the Full Year 1983 CPS and placed into quartiles based on 1983 employment.

b. The loss in employment from imports for industry $i$ from period $t$ to $t^{\prime}$ is defined as $\left[\left(M_{i t^{\prime}}-M_{i t}\right) \cdot(L / Q)_{i}\right]$, where $M$ is imports and $(L / Q)_{i}$ is the ratio of employment to output in industry $i$ in 1984. Imports and output are measured in quantities with their nominal values deflated by the four-digit SIC industry shipments deflator from the Annual Survey of Manufactures. The gain in employment from exports is analogously defined with exports replacing imports.

the increase in the trade deficit was associated with a reduction of 1.4 million workers producing traded manufacturing goods. More than 600,000 , or 45 percent, of these workers had been employed in the quartile of industries that paid the lowest wages. This reflects the substantial increase in import penetration in industries like apparel during the early 1980 s.

These results conflict dramatically with the popular view that the United States is being forced from cutting-edge industries. We suspect this misconception stems from the fact that traded goods industries as a 
whole pay higher wages than the rest of the economy. In a period when the trade deficit rises, good jobs are lost. But these jobs are likely to come back when the trade deficit returns to balance. ${ }^{75}$ There appears to be little evidence through 1984 of relative deterioration in the high-wage portion of the American traded goods sector.

These patterns should not be surprising. Postulate that cutting-edge industries pay wage premiums. Following the discussion of Krugman and Baldwin, assume that other nations are catching up with the United States. ${ }^{76}$ They then make incursions into the least progressive sectors of our economy, causing U.S. workers to move toward high-wage industries.

\section{Conclusion}

Three classes of economic arguments for policies directed at altering the composition of economic activity may be distinguished. One, which has received much attention in recent years, stresses product market imperfections and the assistance government can provide in helping domestic enterprises capture a greater share of monopoly rents in internationally competitive product markets. A second class of arguments stresses that because markets generate substantial industry wage differentials which neither reflect differences in skill nor compensate for differences in working conditions, the market allocation of labor is inefficient. Thus reallocations of labor from low-wage to high-wage industries have the potential to increase output. A third class of arguments relies on externalities. It is suggested that firms in some industries, particularly those involved in high technology, generate external benefits they cannot fully capture. If so, investment in those industries should be encouraged.

Our paper has been concerned only with the first two arguments, because available data permit some estimates of product and labor

75. On the other hand, see Richard Baldwin and Paul R. Krugman, "Persistent Trade Effects of Large Exchange Rate Shocks," Working Paper 2017 (NBER, September 1986), for an argument that transitory exchange rate shocks may permanently affect an economy's ability to compete in some industries.

76. Paul R. Krugman and Richard E. Baldwin, "The Persistence of the U.S. Trade Deficit,' Brookings Papers on Economic Activity, 1:1987, pp. 1-43. 
market rents but do not permit reasonable estimates of the external benefits of production in different industries. Our failure to examine dynamic externality issues reflects only data limitations, not a conviction that they are unimportant. Indeed, that the economy's manufacturing sector accounts for about 20 percent of gross national product and does about 95 percent of its private $R \& D$ suggests that the importance of dynamic externalities may well vary greatly among sectors. ${ }^{77}$

Our data clearly demonstrate that shareholders in American firms receive only very small monopoly rents. For many years one has been able to account for almost all the market value of firms by totaling the value of their tangible assets. In other words, there is little evidence of profit rates far in excess of costs of capital. The weak available evidence suggests that the same situation holds for Japan. Consequently, unless monopoly rents are masked by some other market imperfection, the potential gains from policies directed at shifting them are minor.

We have presented a variety of evidence suggesting that labor rents associated with interindustry compensation differentials are quite large, at least when compared with differences in profit rates. This conclusion holds if only a moderate fraction of interindustry compensation differentials cannot be attributed to differences in working conditions or worker skills. Indirect evidence of labor market rents comes from the observation that substantial interindustry wage differentials remain even when various measures of skill and working conditions are controlled for as well as from correlations of wage differentials and industries' capital intensity and average profitability. More direct evidence comes from comparisons of quit rates and the lengths of job queues in high- and low-wage industries. Even after adjusting industry wage differentials for differences in measured labor force skills and other characteristics, we find that the variation in our measure of labor rents across manufacturing industries is about two to three times as large as the variation in aftertax profit rates.

This comparison of rents to workers and capitalists suggests that if a static efficiency case exists for policies which affect the composition of output, it must rely primarily on the importance of labor market rents.

77. The National Science Foundation reports that in 1984 the manufacturing sector spent $\$ 69$ billion on R\&D and that this total accounted for 96.3 percent of all private R\&D expenditures. Rudiger W. Dornbusch, James Poterba, and Lawrence H. Summers, The Case for Manufacturing in America's Future (Eastman Kodak, 1988). 
The Airbus example implies that under at least some circumstances labor market rents can be sufficiently large to tip the balance in favor of interventionist policies. But before jumping to the conclusion that policies should be directed at encouraging specific high-wage industries at the potential expenses of low-wage ones, several qualifications should be noted.

First, the conclusion that to increase employment in high-wage industries is desirable rests on the nature of industry wage differentials. If these differentials reflect differences in worker ability, or compensate for differences in working conditions, encouraging growth in high-wage industries makes no sense. Even though wages are higher in Alaska than in other parts of the country, few would see a case for encouraging employment in Alaska. And even if workers in high-wage industries do receive rents, the argument for encouraging high-wage employment depends on the premise that the need for firms to pay these rents reduces the level of high-wage employment. If, for example, incompetent employers both paid excessive wages and hired excessively large work forces, a policy of subsidizing high-wage employment would reduce economic efficiency.

Second, granting the existence of disparities across sectors in marginal productivities of labor, the question arises whether the collateral economic costs of policies directed at encouraging high-wage sectors would outweigh the benefits. The collateral costs of such policies include the inequity of essentially taxing low-wage workers to subsidize those with higher wages, the likely encouragement of efforts by workers to seek rents from firms, efforts by industries to distort their compensation schemes in order to win favorable treatment from the government, and the increased queuing that may result from an increase in the number of high-wage jobs. Furthermore, there could be foreign retaliation for subsidies to high-wage domestic producers.

Third, even admitting the economic argument for policies directed at encouraging the growth of high-wage industries and discouraging the growth of low-wage industries, the political consequences of such policies may be questioned. Accepting the principle that some industries are "better" than others might well open a Pandora's box of specialinterest pleading. ${ }^{78}$ Although our skill-corrected wage differential seems

78. See Charles L. Schultze, “Industrial Policy: A Dissent," Brookings Review (Fall 1983), pp. 3-12, for a particularly cogent set of warnings. 
a more precise and defensible criterion for assessing industries than those suggested by industrial policy advocates in the past, it is certainly not the only justification that could be given for helping an industry. Industries can, for example, be expected to argue that they should be assisted because their workers, if displaced, would remain unemployed.

Despite these qualifications, we believe wage differentials should be one of the factors considered in the design of sectoral policies. In considering the merits of different import protection policies, we find it relevant that displaced steelworkers tend to move slowly to much lower wage jobs, whereas displaced textile workers are reemployed more quickly and do not usually suffer such large wage losses. ${ }^{79}$ And in choosing between a strategy of import protection and export promotion for our manufacturing sector, it seems very relevant that American export-intensive manufacturing industries provide better jobs than our more import-intensive industries. It seems equally relevant that labor appears to capture a significant fraction of the fruits of investments in research and development and plant and equipment. These observations suggest yet another rationale for policies aimed at increasing our low rate of national investment.

\section{Appendix: Data Set Construction and Sources}

\section{Capital Rents Measures}

Measures of industry-level capital rents for three-digit CIC manufacturing industries were computed from data on individual firms contained in the NBER R\&D Master File. This panel data set consists of up to twenty-seven years of data (1959 to 1985) for every U.S. manufacturing sector company that existed for three or more years sometime between 1976 and 1985 and was on one of Standard and Poor's COMPUSTAT Files as of 1978-80. The data base's contents and construction are

79. Using the January 1984 Displaced Workers Survey, Kruse finds that reemployment earnings were on average 25.1 percent below pre-displacement earnings for workers displaced from primary metals industries in the 1979 to 1983 period. On the other hand, the typical displaced textile worker experienced 0.5 percent wage increase over his or her pre-displacement earnings. Furthermore, the median weeks of joblessness following displacement was 46 weeks for displaced primary metals workers and 13 weeks for displaced textile workers. Douglas L. Kruse, "International Trade and the Labor Market Experience of Displaced Workers, Industrial and Labor Relations Review, vol. 41 (April 1988), p. 407. 
described in Bronwyn H. Hall, Clint Cummins, Elizabeth S. Laderman, and Joy Mundy, "The R\&D Master File Documentation," NBER, Stanford, Calif., October 1988. Our calculations are based on the October 1988 updated version of the data set provided to us by Bronwyn Hall. This data set has the advantage of allowing us to compute capital rents measures based on both market value and accounting profits for a consistent set of firms.

The calculation of industry-level capital rents used the following firmlevel variables from the R\&D Master File (variable names are in parentheses):

Market value of the firm $(V A L)$. The sum of the value of the preferred stock, the common stock, the long-term debt adjusted for its age structure, and the short-term debt, less the value of net short-term assets.

The inflation-adjusted capital stock (NETCAP). The sum of the net value of plant and equipment, the value of inventories, and investments in unconsolidated subsidiaries, others, and intangibles, all adjusted for inflation.

After-tax net income (NINC). Gross cash flows less the inflationadjusted value of depreciation. Gross cash flows are defined as the sum of income before extraordinary items, depreciation, and interest income less an inventory valuation adjustment and an imputed income from short-term assets.

SALES. Net sales, COMPUSTAT item \# 12.

These variables were used to compute the following firm-level measures for each firm in our sample for each year:

$$
\begin{aligned}
q & =V A L / N E T C A P, \\
N R A T E & =\text { NINC/NETCAP }=\text { the after-tax profit rate, } \\
S C A P & =S A L E S / N E T C A P .
\end{aligned}
$$

The construction of annual industry-level capital rents measures required aggregating the individual firm-level $q$, NRATE, and SCAP variables to three-digit (CIC) industries and weighting each firm's observation by its NETCAP for each year from 1960 to 1985. Each firm was placed into a three-digit (CIC) industry on the basis of its COMPUSTAT four-digit (standard industrial classification, SIC) industry code. Smoothed $q$-ratio and profits measures for each industry for the 196085 and 1981-85 periods were created by computing the arithmetic averages of the annual industry average measures of $q$, NRATE, and 
profits over sales (NINC/SALES) for the relevant period. Smoothed industry level (after-tax) profits in 1984 dollars (PROFITS) were computed by multiplying the 1960-85 smoothed value of NINC/SALES by 1984 industry shipments in current dollars from the 1985 Annual Survey of Manufactures: Statistics for Industry Groups and Industries (ASM). Our smoothed profits measures using only COMPUSTAT firms turn out to be similar to overall industry profits measures from the national income and products accounts (NIPA). For the 1960 to 1985 period, the average ratio of profits to the sum of total employee compensation and profits is 0.14 in NIPA and 0.135 for our COMPUSTAT-based profits measure. This shows that the COMPUSTAT firms used to compute our industry capital rents measures are reasonably representative in terms of profitability. Profits per worker in 1984 dollars are given by PROFITS divided by the industry 1984 employment level from the ASM. Smoothed before-tax profits for the 1960-85 period were computed by multiplying PROFITS for $1960-85$ by the average value from 1960 to 1985 for the relevant two-digit industry of the ratio of corporate before-tax profits to the sum of corporate after-tax profits and net interest.

\section{Labor and Total Rents Measures}

Labor rents as a fraction of total compensation in an industry are given by the share of employee compensation that represents an industry wage premium above the earnings of "observationally equivalent" workers in some base industry. The industry wage differentials used in our three-digit census industry measures of labor rents for manufacturing industries were estimated from an OLS ln earnings regression based on the Full Year 1984 Current Population Survey (CPS) microdata file. The industry wage differentials are the coefficients on the three-digit industry dummies included in the regression. The regression also included six age dummies; six age-sex interaction terms; two-digit industry dummies for industries outside manufacturing; education and its square; eight occupation dummies; a female dummy; a race dummy; an SMSA dummy; three region dummies; interactions of the female dummy with marriage, education, and education squared; and a constant. The sample used includes private sector, nonagricultural employees with complete information available on all the variables used in the regression. The sample size is 118,041 . The ln industry wage differentials are normalized so that 
the lowest wage differential industry in manufacturing, industry 151 (apparel and accessories, except knit), takes on a value of 0 .

Industry labor rents are given by

$$
\text { labor rents }=[W D /(1+W D)] \cdot \text { total employee compensation, }
$$

where $W D=\exp (P)-1$, and $P$ is the normalized industry ln wage differential.

Industry total rents are defined as the sum of labor rents and capital rents.

\section{Data from the NBER Trade and Immigration Dataset}

Three-digit (CIC) industry trade flow measures were computed from the NBER Trade and Immigration Dataset maintained by the Labor Studies Group at the National Bureau of Economic Research. This data set contains trade, employment, wage, immigration, output, and other information for 450 U.S. manufacturing industries (by four-digit SIC code) for the 1958 to 1985 period. The construction of the trade flow variables is described in detail in John M. Abowd and Richard B. Freeman, "Internationalization of the U.S. Labor Market," NBER, August 1986. The contents of the data set are described in NBER Labor Studies Group, "Documentation for Trade and Immigration Datasets," revised July 1987. The import, export, and shipments data for four-digit SIC manufacturing industries for 1984 used in the construction of import and export ratios are from the Trade Monitoring System database, a data bank developed by the U.S. Bureau of Labor Statistics. We aggregated the four-digit SIC level information on imports, exports, and shipments to three-digit census industries to compute our import and export ratios. Industry employment, value-added, and capital stock variables contained in the data set are from the ASM.

\section{Other Measures of Industry Characteristics}

The industry characteristics variables for three-digit census manufacturing industries used in tables 9, 10, and 14 come from various sources. Value added per worker, the capital-to-labor ratio, ln employment growth from 1973 to 1984 , and percent production workers were computed using the ASM data contained in the NBER Trade-Immigration- 
Labor Market Data Set. The other variables excluding the capital and labor rents measures are from the Dickens-Katz 1983 Industry Data Set described in William T. Dickens and Lawrence F. Katz, "Inter-Industry Wage Differences and Industry Characteristics," in Kevin Lang and Jonathan S. Leonard, eds., Unemployment and the Structure of Labor Markets (Basil Blackwell, 1987), pp. 48-89. Percent unionized, average years of schooling, average years of experience were all computed from the Full Year 1983 CPS. Percent black is from Bureau of the Census, 1980 Census of Population, vol. 1: Characteristics of the Population, Detailed Population Characteristics, pt. 1: United States Summary, Section A: United States (Department of Commerce, 1984), table 286. Percent female is from Employment and Earnings, vol. 30 (March 1983), tables B-2 and B-3. The average hourly wage for production workers is from Employment and Earnings, vol. 31 (March 1984), table C-1. The four-firm concentration ratio is computed by value of shipments and is from Bureau of the Census, 1977 Census of Manufactures: Subject Statistics, vol. 1 (Department of Commerce, 1981), table 8. R\&D expenditures over sales is from National Science Foundation, $R \& D$ in Industry, 1981, tables A1, B3, B5, B11. Average number of employees per establishment is from Bureau of the Census, General Report on Industrial Organization: Enterprise Statistics (Department of Commerce, 1981), table 4. 


\section{Comments and Discussion}

Robert E. Hall: Branches of economics can be distinguished by the dimension on which they focus to interpret variations in economic activity. In macroeconomics the dimension is time: we want to know why output is 5 percent higher in booms than in recessions. In development and comparative economics, the dimension is across countries: we want to know why real income is twenty times higher in Sweden than in China. In regional economics the dimension is geographic within the same country. In labor the dimension is across individuals. Katz and Summers make a contribution to the field whose dimension is across industries. I am not sure what name to give this field, but it is an important one.

The main point of the paper is, or ought to be, that the value of output per unit of input is substantially higher in some industries than in others. This finding is a mystery on the same footing as the mystery of higher output per unit of input in booms, in highly developed countries, in prosperous cities and regions, and among more successful individuals. The magnitude of the unexplained variation of output across industries is greater than the unexplained variation of output over the business cycle. It is radically smaller than the variation across the countries of the world. It is much smaller than the unexplained variation in earnings of workers in the United States or in any group; there is much more unexplained variation in the earnings of those attending this conference, all of whom have essentially the same education and other observed attributes, than there is across the industries in the Katz and Summers paper. Finally, there is substantially more geographic variation in output per unit of input in the United States than the authors find for their industries. In other words, except for the rather minor variations studied 
by macroeconomists, the finding of unexplained differences in productivity in this paper is more subtle than those studied in other branches of economics.

I think it is useful to consider possible common features of these unexplained variations along different dimensions. In particular, the idea of agglomeration has always been important in regional economics, and I believe it should be important in explaining variations in economic activity over time, across countries, and across industries. Spatial agglomeration is so obvious that it requires little further comment. Spatial hot spots like New York City have high productivity because transportation and coordination costs are lower than in other locations with lower densities. Agglomeration is also important in understanding economic development. National productivity rises as an economy makes the transition from low-density peasant agriculture to high-density urban production. In recent research Kevin Murphy, Andrei Shleifer, and Robert Vishny have worked on both the business cycle and development within this kind of framework.

Katz and Summers do not state their findings across industries in terms of productivity. Rather, they examine the incomes derived from the various industries by the shareholders and workers. In the absence of unexplained differences, shareholders should all earn the market return on the capital installed in the industry and all workers should earn the same market wage. Equality of shareholder earnings is very nearly satisfied, but equality of wages fails unambiguously. In industries with high value of output per unit of input, the workers, not the shareholders, capture the extra dividend.

I find the empirical evidence on this point reasonably convincing. The fact that workers moving from low-wage to high-wage industries receive essentially the full cross-sectional difference in wages is quite damaging to the theory of sorting on unobserved differences in productivity. Still, one needs to be careful here because the magnitude of the industry differences-plus or minus 20 percent after adjustment for observed characteristics-is small in relation to unexplained variations in wages across individual workers.

The authors also produce evidence that the labor market is not in equilibrium in order to support their view of the industry wage differentials. I find this evidence less convincing. First, they show that quits are somewhat lower in industries with wage premiums. An industry with a 
10 percent wage premium has 0.9 quits per 100 workers a month, as against 1.3 quits in an industry with no premium. The problem is that quits are concentrated almost entirely among entry-level workers. The data on job tenure show that only 0.2 or 0.3 percent of workers with five or more years on the job leave their jobs each month, and that most of these separations are layoffs, not quits. The correct interpretation of the paper's finding is that new workers in high-wage industries quit very often. If the labor market is truly in disequilibrium, it is hard to see why the worker who has had to put great effort into finding a good entry job would then quit. Long lines outside the plant should make those inside the plant stick tenaciously to their jobs, which is not at all what the authors find.

The other evidence on disequilibrium is only sketchily summarized. Industries with wage premiums attract larger numbers of applicants for job openings. No quantitative measure of this effect appears in the paper. A worker with a discount rate of 10 percent should be willing to invest 200 hours of job-seeking activity to raise his wage rate by 1 percent. Thus even a very small wage premium should generate huge lines and other types of rent-seeking behavior.

My impression is that the labor market is not in nearly as much disequilibrium as Katz and Summers' view requires. Workers move into premium jobs quite fluidly. Employers in industries like communications that pay substantial premiums feel that if they don't keep up with the industry norm, they will not be able to attract qualified workers. Of course, this is not an absolute rule-job rationing does occur and some employers turn away droves of fully qualified job aspirants. On the other side, the restaurant industry, where typical compensation is 28 percent below the norm (see table 2), does not seem to have trouble filling its positions. Furthermore, I cannot help feeling that the idea of raising wages a bit to get qualified help is not unknown in that industry.

Katz and Summers conclude from their study of wage differentials that the value of the marginal product of labor is not equated across industries, a failure of a fundamental condition for allocative efficiency. They recognize that the inference is not airtight-employment contracts could set labor input to satisfy the efficiency condition and then pay out dividends to workers in a way unrelated to the amount of work. They do not take this possibility seriously, and I do not have strong evidence they are wrong. Based on the inference, the appropriate corrective action 
is a policy to encourage employment and output in high-wage industriesan industrial policy. A negative excise tax on output or a wage subsidy would do the trick. Policies for encouraging exports would also help, since exports tend to come from the high-wage sector.

In thinking about the desirability of an industrial policy, it is helpful to return to the analogy between industry productivity differentials and differences along other dimensions. The macroeconomic analogy is as follows. Booms are times of high productivity, when the intertemporal value of the marginal product of labor exceeds its value at other times. Hence the appropriate policy, following the Katz-Summers logic, is to encourage more output during booms. Recessions are like the apparel industry: policy should encourage low employment and output during times of low productivity. Thus the logical extension of the KatzSummers industrial policy is a procyclical policy, such as raising excise taxes in recessions and lowering them in booms. This may not be a completely bad idea. Michael Knetter observes that the modern view of a boom is a coordination success, just as a recession is a coordination failure. ${ }^{1}$ Possibly we should use fiscal policy to take further advantage of a coordination success, just as Katz and Summers would have us take further advantage of the benefits of production in a high-productivity industry. But if the authors do not believe in procyclical fiscal policy, as I suspect they do not, then they need to explain why the government should encourage the output of highly productive industries but not the output of highly productive time periods.

The spatial analogy of the Katz-Summers approach to industrial policy has a similarly perverse flavor. If one applied the full battery of their empirical techniques to data on wages by location instead of by industry, the results would be even more dramatic. Wages are much higher in New York City than in the country as a whole, and the premium is about the same for all occupations. People moving from Ohio to New York receive the full cross-sectional wage differential: almost none of the New York premium can be attributed to superior unobserved characteristics of workers there. Higher productivity in New York is a failure of a fundamental condition of geographic efficiency. The answer is to subsidize output and employment in New York and other high-

1. Michael Knetter, "Adjustment Costs and Economic Fluctuations," unpublished paper. 
wage areas. Again, I am not sure that is a bad idea. But I doubt if the authors would approve of this extension of their thinking, and I would learn a lot from their explanation of what is wrong with the idea.

The spatial analogy is particularly important because I do not believe there is an important geographic disequilibrium in the U.S. labor market. No force prevents workers from relocating to New York and, now at least, jobs are easy to find there. Hence the disequilibrium hypothesis breaks down in the geographic dimension, just as I suspect it breaks down in the industry dimension (though I think it is still viable in the time dimension). An interesting, open question is whether the industrial policy recommendation rests on the disequilibrium hypothesis. I am not sure that it does, but the authors' argument for stimulating the high-wage sector does rely on disequilibrium. Further consideration of increasing returns and other features of agglomeration might lead to a different rationale for industrial policy. Murphy, Shleifer, and Vishny's model of development admits an important role for the government in stimulating development. ${ }^{2}$

The paper closes the book on industry wage differentials with its encyclopedic review of the very thorough recent research on the topic. It only just gets started on the next issue: the interpretation of the finding of large true differentials and the formulation of appropriate policy to take advantage of them.

Charles L. Schultze: I want to call attention to one disturbing aspect of Katz and Summers' empirical results. In table 2 the difference between the "without controls" (col. 1) and the "with controls" (col. 2) wage premiums is a linear combination-that is, an index-of the effect of the demographic control variables on wages. Yet when I regressed that index of the control variables on the "purged" wage premiums in the second column (which presumably represent wage differentials after the effect of demographic and other control variables has been removed), I nevertheless obtained a high $R^{2}$ of 0.6 . The standard deviation of the remaining wage differentials was 10 percent, not the 15 percent that Katz and Summers find.

This result could occur if the factors accounting for industry wage premiums-either unobserved personal qualities or industry character-

2. Kevin M. Murphy, Andrei Shleifer, and Robert Vishny, "Industrialization and the Big Push,”' Working Paper 2708 (Cambridge, Mass.: NBER, September 1988). 
istics associated with the payment of efficiency wages-were themselves positively correlated with the index of demographic variables. The coefficients on the demographic variables were derived by regressing wages across the entire sample of 116,387 on the demographic characteristics of individual workers, not by regressing industry average wages on industry average characteristics. Thus if industries in which such factors as the avoidance of shirking and the acquisition of firm-specific skills were particularly important also happened to be industries that tended to hire better educated people, a higher proportion of managers or experienced workers, a large fraction of male employees, or employees with other high-wage demographic characteristics, their wage premiums, purged of demographic factors, could nevertheless be positively correlated with industry average demographic characteristics. To say it another way, the industry wage "residuals" would themselves be correlated with industry average demographic characteristics along one or more dimensions.

The problem is that the correlation I found between the Katz-Summers residual wage premiums and the index of industry average demographic characteristics could have arisen from two causes-one favorable to and one destructive of their maintained hypothesis. The association could have arisen because unobservable personal characteristics are correlated with the observable ones, in which case the wage premiums do not represent rents. If, however, the correlation is between industry characteristics giving rise to efficiency wages and industry average demographic characteristics-as in the example cited earlier-this fact does not weaken the Katz-Summers hypothesis that the premiums embody rents. Katz and Summers argue that the latter explanation is the correct one. I am inclined to suspect there must also be a good bit of the former explanation present.

According to the data in table 3, where Katz and Summers repeat their exercise within selected three-digit occupational categories, "managers, not elsewhere classified," appear to receive extremely low wages (even after removal of demographic effects) in such industries as restaurants, entertainment, and personal services, and very high wages in machinery, chemicals, communications, and public utilities. But is this really surprising? Imagine two male thirty-year-old college graduates in Detroit, one of whom manages a Kentucky Fried Chicken outlet and the other is a manager at Chrysler. Which one does your common sense tell 
you is likely to exhibit higher personal qualifications? Do you really think all the wage differential is rent? My own sense tells me that some of the wage difference results from self-sorting by various kinds of abilities or characteristics, such as stability of job attachment and ability to take responsibility. Or again, imagine two male thirty-year-old college graduates, one of whom runs a movie house in Hartford, Connecticut, and the other is a "manager, n.e.c." with Prudential Insurance. Ask yourself, do you think all the difference is rent?

Also, consider an industry whose technological or other characteristics require it to "buy" low absenteeism. Presumably the efficiencywage argument may hold. That is, the industry has to pay a high wage to get low absenteeism. The unemployed worker in the job queue cannot credibly demonstrate that he is not going to be a frequent absentee, and therefore the wage premium may be ineradicable. Nevertheless, not all the wage premium is likely to be rent. Those workers who are sporadically prone to take a few days off will gradually be eliminated from that industry, and many others may never even try to enter it because they know the likelihood of being fired for absenteeism. To some extent the same phenomenon is probably true of work effort, willingness and ability to take responsibility, and other personal characteristics.

And so, given the breadth of their occupational characteristics, some of Katz and Summers' differentials may arise from ability differentials not correlated with observable characteristics. Wage differentials representing industry rents not associated with personal characteristics may indeed exist, but the evidence is not convincing that they are anywhere near as large as those shown in table 2.

I also want to question Katz and Summers' view about the stability of industry wage premiums. Table 2 lists six industries with very high premiums after the effects of demographics have been removed: mining, transportation equipment, tobacco, petroleum, communications, public utilities. For my analysis, I took those industries, each with a premium (after controls) of 20 percent or more, and added primary metals (premium 16.4 percent). During the late 1960s and 1970s these seven industries, all of which are either regulated or oligopolistic and have strong unions, experienced very large increases in wages relative to the national average.

Based on Bureau of Labor Statistics average hourly earnings data (adjusted upward for fringes by the same technique as that used by Katz 
and Summers), the weighted average "raw" wage premium for those seven industries, relative to the overall average for the private nonfarm economy, rose from 32 percent in 1966 to 50 percent in $1980 .{ }^{1}$ Thus almost 20 percentage points of the 1980 premium did not exist in the late 1960s. This suggests to me that the stability of these premiums is not large and that some part of what Katz and Summers observed from 1984 data may be the residue of a particular phenomenon that happened during the late 1960s and 1970s.

Robert H. Topel: The purpose of Katz and Summers' paper is to survey the evidence supporting efficiency wage theories of the labor market and, using that evidence, to make a brave case for an activist policy of subsidizing certain high-wage industries. The paper presents a fairly balanced discussion of issues about which the authors and I disagree. If the policy prescriptions they suggest were adopted, the outcome would be nothing less than a radical transformation of the allocation of resources in the U.S. economy.

The central argument of the paper evolves in the following way, each step of which is essential.

1. Workers in certain identifiable industries are receiving systematic rents from their employment relationships. These rents are reflected in wages that greatly exceed those available in the workers' best alternatives. Thus workers in high- and low-wage industries could exchange positions, and the value of social output would not fall.

2. The wage differentials underlying these rents lead to false price signals for employers and therefore to distortions in employment decisions. Employment is too low in high-wage industries because of the tax imposed by noncompetitive wage differentials.

3. These distorted price signals can be offset by appropriately designed Pigovian taxes and subsidies.

4. Policymakers are sufficiently well informed to carry out these policies in a Pareto-improving way.

Given these points, the paper makes cogent arguments about how trade is distributed among high- and low-wage industries and the implications of product market rents for policy. In my view these arguments

1. Employment weight for each of the seven industries was the average of its 1966 and 1980 production worker employment. 
are secondary to the theme of systematic labor market rents, so I will not focus on them. The weak links in the analysis occur in the four points I have outlined.

Are workers receiving rents of the type mentioned above? The main evidence on this is found in table 2 of the paper, which illustrates proportional industry wage differences relative to the mean. These differences are large. There are at least two important explanations for them that do not involve systematic rents or labor market distortions. First, people in high-wage industries may be more productive, so the wage differentials illustrated in the table reflect a sorting of individuals across industries based on productivity. Persons who work in the communications industry, on this argument, are more productive than private household workers. Second, the differentials partly reflect characteristics of jobs that are poorly quantified in the survey data available to econometricians. Miners, who work in dark holes in the ground, earn more than restaurant waiters for well-understood reasons.

The authors acknowledge these points, yet here and elsewhere in this literature the empirical strategy is a remarkable one. Essentially it is this: any wage differences that remain after controlling for observed characteristics of workers and their jobs are claimed as evidence of efficiency wages and therefore as a basis for policy interventions of the most extreme sort. This is close to claiming the residual of a regression as one's own and challenging all comers to explain it away.

Suppose you believe, as I do, that the sorting on productivity explanation is important. In survey data like the CPS, one finds a limited number of personal characteristics that may be associated with a person's true productivity: age, reported years of schooling, marital status, and so on. Casual observation suggests that the amount of remaining heterogeneity of productivities after controlling for these factors is huge. For even the best-fitting wage regressions can account for only about a third of wage inequality. Even so, controlling for these observable correlates of productivity should reduce the magnitude of industry wage differences so long as (1) there really is sorting on true productivity, and (2) these observables are correlated with true productivity. In terms of the estimates in table 2, all estimated differentials should move toward zero after conditioning on observable correlates of unobserved productivity. In fact, the data are not so kind: this happens only in 90 percent (thirtysix out of forty) of all cases reported in the table. The only important 
exception to that prediction among these industries is in educational services, where it turns out that teachers have high levels of schooling but rather low wages (for reasons that we understand but that are not in the data). Thus conditioning a wage regression on years of schooling gives teachers a large negative differential. I doubt that this has important implications for industrial policy.

This pattern of declining differentials is strong evidence that productivity-based sorting is an important determinant of observed industry wage differences. Evidence on this point is presented in my table 1, which shows in column 1 the coefficients on observed characteristics from a standard log wage regression. The data, drawn from the March CPS files for 1977-1985, are for males. Columns 2 and 3 report coefficients

Table 1. Estimated Effects of Observable Characteristics in Log Wage and Sorting of Equations ${ }^{\text {a }}$

\begin{tabular}{|c|c|c|c|}
\hline \multirow[b]{2}{*}{ Item } & \multicolumn{3}{|c|}{ Dependent variables } \\
\hline & $\begin{array}{l}\text { Ln wage } \\
\text { (I) }\end{array}$ & $\begin{array}{l}\text { Industry and } \\
\text { occupation } \\
\text { effects } \\
\text { (2) }\end{array}$ & $\begin{array}{c}\text { Industry effect } \\
\text { (3) }\end{array}$ \\
\hline Education & $\begin{array}{c}0.0815 \\
(0.0004)\end{array}$ & $\begin{array}{c}0.0182 \\
(0.0002)\end{array}$ & $\begin{array}{c}0.0059 \\
(0.00014)\end{array}$ \\
\hline Experience 1 & $\begin{array}{c}0.0750 \\
(0.0015)\end{array}$ & $\begin{array}{c}0.0108 \\
(0.0005)\end{array}$ & $\begin{array}{c}0.0080 \\
(0.0004)\end{array}$ \\
\hline Experience 2 & $\begin{array}{c}-0.0025 \\
(0.0001)\end{array}$ & $\begin{array}{c}-0.0004 \\
\left(4.3 E^{-5}\right)\end{array}$ & $\begin{array}{c}-0.0003 \\
\left(3.4 E^{-5}\right)\end{array}$ \\
\hline Experience 3 & $\begin{array}{c}3.3 E^{-5} \\
\left(3.6 E^{-6}\right)\end{array}$ & $\begin{array}{c}7.4 E^{-6} \\
\left(1.2 E^{-6}\right)\end{array}$ & $\begin{array}{c}6.6 E^{-6} \\
\left(1.0 E^{-6}\right)\end{array}$ \\
\hline Experience 4 & $\begin{array}{r}-1.3 E^{-7} \\
\left(3.6 E^{-8}\right)\end{array}$ & $\begin{array}{r}-3.0 E^{-8} \\
\left(1.3 E^{-8}\right)\end{array}$ & $\begin{array}{r}-4.9 E^{-8} \\
\left(1.0 E^{-8}\right)\end{array}$ \\
\hline Married & $\begin{array}{c}0.1654 \\
(0.0027)\end{array}$ & $\begin{array}{c}0.0371 \\
(0.0010)\end{array}$ & $\begin{array}{c}0.0199 \\
(0.0008)\end{array}$ \\
\hline Central city & $\begin{array}{c}-0.0951 \\
(0.0029)\end{array}$ & $\begin{array}{c}-0.0265 \\
(0.0010)\end{array}$ & $\begin{array}{c}-0.0147 \\
(0.0008)\end{array}$ \\
\hline SMSA & $\begin{array}{c}0.1059 \\
(0.0027)\end{array}$ & $\begin{array}{c}0.0043 \\
(0.0009)\end{array}$ & $\begin{array}{c}-0.0021 \\
(0.0008)\end{array}$ \\
\hline Black & $\begin{array}{c}-0.1828 \\
(0.0044)\end{array}$ & $\begin{array}{c}-0.0357 \\
(0.0016)\end{array}$ & $\begin{array}{c}0.0041 \\
(0.0013)\end{array}$ \\
\hline Mean square error & 0.2116 & 0.0267 & 0.0169 \\
\hline
\end{tabular}

a. All models also contain year dummies for 1978-85 and nine region dummies. Numbers in parentheses are standard deviations. 
from regressions of estimated occupation and industry wage differentials on the same set of characteristics. The message of the table is straightforward: observable dimensions of productivity that typically raise wages-education and experience, for example-are also associated with employment in high-wage industries. So long as employers sort on unobservable (to econometricians) dimensions of ability in anything like the same way they sort on observed productivity, this evidence implies that estimated industry wage differentials are overstated. In my work with Kevin M. Murphy we find that the extent of this bias is large. Specifically, we conclude that if sorting on unobservables occurs in the same way as sorting on observable dimensions of productivity, then about 75 percent of the variation in estimated industry wage differentials is illusory. And it seems plausible that people's unrecorded characteristics may be even more important in sorting people among sectors than the rather poor correlates of productivity available in survey data. That is why employers pay observationally equivalent people systematically different amounts. If so, our estimates of the effects of sorting may be conservative.

Statistical issues aside, the idea of moving from unexplained wage differences to policy strikes me as reckless. Suppose instead that Summers and Katz had been interested in regional policies (as I fear they could be). The procedures that underlie table 2 could be reproduced: there are large wage differences among areas, and workers in the South earn less than those in the Northeast. Further, that has always been true, so the differentials would be highly persistent over time. Controlling for observable characteristics of people, jobs, and locales will not make the differences go away, but it will make them smaller. In fact, all arguments about industry differentials would also seem to apply to regional wage differences. Can we then conclude from this "evidence" that a policy of locational subsidies is warranted, that too few people live in the Northeast? I would not.

As another example, consider the market for economists, which we all know something about. In terms of the type of survey data marshaled by Katz and Summers, all of us have identical "observable" characteristics. We all have the same kind of job, exactly the same years of schooling, and even the same degree. Yet probably full professors working in the top departments earn about 25 percent more than the average, while those in liberal arts colleges earn substantially less. Thus 
there are large "departmental" wage differences, which most economists would attribute to differences in the research and other output of the faculties. (Publication rates would show similar "unexplained" differentials.) In most respects the data would be indistinguishable from the industry wage premiums of which so much is made in this paper. I conjecture that the top departments provide larger offices, offer more capital and research support, and may even have higher-paid secretaries.

Advocates of efficiency wages are notoriously difficult to pin down on which of the many available models they think is relevant. So if one theory is questioned, a new one can be adopted, and then the chase is on. Sometimes reference is made to efficiency wage "considerations," which is an unassailable position. A refreshing aspect of this paper is that the authors are clear about the economic forces they believe support wage differences. The theory they advocate is rent sharing or rent extraction: either management simply shares product market rents with workers, or workers engage in some collective action that achieves the same thing. For the purposes of what the authors want to accomplish, however, this model is troubling.

As regards rent extraction, the policy prescriptions of the paper require that the wage be used by labor as a single instrument to capture a larger share of the pie. If only the wage is increased because of labor's power or management's generosity, then employment decisions are distorted and policy implications follow. But Leontief's insightful critique of traditional union models seems appropriate here: if sharing the pie is the goal, the pie should first be made large. Then employment decisions are undistorted even by true wage differentials and the case for activist industrial policy is nonexistent. Evidence that employment decisions are truly distorted is hard to come by, but it is necessary to make a convincing case for policy intervention.

A related point applies to simple rent sharing: employment decisions are distorted if the wage is treated as the marginal cost of employment. But if rents are being shared, why not spread them over the right number of workers, or even too many, rather than too few? Then high-wage industries may be inefficiently large. The theory, such as it is, is not precise enough to reach any conclusions on these key points.

I do not want to leave the impression that I disagree with all the conclusions and policy prescriptions of this paper. For example, the authors conclude that interindustry variation in product market rents is 
fairly small and that the level of monopoly profits in these industries is practically nil. Thus there is no systematic evidence to support an activist industrial policy designed to correct monopoly distortions. I agree.

\section{General Discussion}

The empirical evidence presented by Katz and Summers convinced nearly all the conference participants that significant unexplained differences in worker earnings between industries exist and seem to persist over time and across national borders, and that these differences probably are important for policy. But most participants took issue with the authors' conclusions that these differences represent rents, arguing instead that the unexplained wage differentials derive from some kind of unobservable or unmeasurable difference in the quality of the workers or in the nature of the work being done. And nearly all participants disputed the appropriateness of the authors' policy conclusion that highwage industries should be subsidized to encourage expansion of employment in them. William Nordhaus asserted that the authors move too quickly to the policy conclusions; until they have understood the reasons for the differentials, he questioned their ability to draw valid conclusions. Commenting on the correlation between the measurable demographic effects and the remaining industry wage premiums that Charles Schultze had observed, Zvi Griliches and Ariel Pakes suggested that this evidence not only fails to rule out an unobservable characteristics interpretation but is not even particularly supportive of a rent-sharing or efficiency wage interpretation. Martin Baily noted that this interpretation must show why it is that in some industries workers must be motivated more highly than in other industries.

Mike Scherer suggested that the degree of sensitivity of the capital stock in an industry to the decisions and actions of workers might explain these differences. But Nordhaus and Richard Schmalensee both thought the evidence in the paper worked against the efficiency wage theory, since, as Nordhaus put it, it seems unlikely that janitors or secretaries are any more likely to shirk in the tobacco industry than in the apparel industry.

Schmalensee said he finds the rent-sharing argument "congenial" and consistent with evidence from antitrust cases that anticompetitive 
behavior does not necessarily lead to higher profit rates. But he noted, the wage premium is virtually uncorrelated with either profit rates or concentration ratios, both of which are usually associated with the market power and the ability to earn rents.

On the other hand, participants took issue with Robert Hall's arguments that the observed level of queuing for high-wage jobs is too low to support the conclusion that the high wages are a consequence of high rents. Griliches observed that if the queue is already long when the job seeker arrives, the probability that he will actually get the hoped-for job may appear quite low and therefore reduce the expected value of the job by enough to make it no longer worth entering the queuing. Summers pointed out that the quit rates also act like a discount rate in reducing the expected value of the higher-wage job.

Regarding the policy implications of the wage differentials, Griliches, like Hall, drew an analogy between the observed interindustry differentials and geographic and intertemporal wage differentials. Griliches said such differentials may arise as a result of some economic shock and, in fact, represent disequilibriums that may take years to correct. But the appropriate policy response should be to subsidize information and resource mobility rather than directly subsidize the high-wage sectors. Likewise, Nordhaus noted that, while incomes often converge very slowly in the aftermath of a shock such as the Civil War, they do eventually tend to converge. As they converge, the case for policy intervention is weakened. Katz and Summers responded by pointing to the evidence in the paper showing the tremendous persistence of the differentials. There is not much sign of convergence.

Judd observed that many of the industries with high-wage differentials also have high price-cost margins but zero excess profits. Together these characteristics suggest that the industries in question are monopolistically competitive, not monopolies. If that is true, he said, the policy recommendations of the authors may be inappropriate, since in this case subsidizing variable inputs "could be just as likely to reduce welfare as increase welfare." He also argued that analysis of welfare economics in models of imperfect information "yield notoriously fragile results." Thus he cautioned that "any sort of policy prescriptions using these kinds of arguments are going to rest on very thin ice."

Summers countered a few of the points made by participants. He argued, for example, that the unobservable characteristics explanation 
of the wage differentials "does not fit very naturally with the observation that the industries that have higher capital-labor ratios and more profits pay higher wages." Although he conceded that capital and unobserved skill characteristics might be complements for some kinds of workers, he maintained that it was stretching this point too far to suggest that the skills needed by secretaries or janitors have strong complementarities with capital. He also took issue with Hall's analogy between the interindustry wage differentials and regional wage differentials, noting that there are no significant differences in quit rates between regions. The test of whether the analogy is valid, he argued, is whether workers in Mississippi envy workers in New York. "The logic of our argument is that workers in low-wage industries do envy workers in high-wage industries and would like to take their place," he said. "If that is not true, then there is obviously no argument for policy."

On the other hand, Summers contended, in comparing policies that protect the steel industry with policies that protect textiles, it should be regarded as relevant that displaced steel workers typically are out of work for nearly a year and end up somewhere else earning 25 percent less, whereas displaced textile workers usually find a job again within three months, earning about the same as they had earned before. Such questions about the labor market rents, he asserted, are "much more important and relevant for any question of policies towards industries" than discussions of oligopoly or monopoly rents, since the latter are so small by comparison. He acknowledged Judd's comment about the importance of monopolistic competition, but argued that welfare would be enhanced by increasing employment of high-wage workers in monopolistically competitive industries. 